\title{
Incretin treatment and risk of pancreatitis in patients with type 2 diabetes mellitus: systematic review and meta-analysis of randomised and non-randomised studies
}

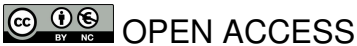

Ling Li research associate ${ }^{12}$, Jiantong Shen lecturer ${ }^{3}$, Malgorzata M Bala research fellow ${ }^{4}$, Jason W Busse assistant professor ${ }^{567}$, Shanil Ebrahim assistant professor ${ }^{5689}$, Per Olav Vandvik associate professor $^{1011}$, Lorena P Rios endocrinologist ${ }^{12}$, German Malaga associate professor ${ }^{13}$, Evelyn Wong resident physician ${ }^{14}$, Zahra Sohani PhD candidate $^{515}$, Gordon H Guyatt distinguished professor ${ }^{516}$, Xin Sun senior scientist ${ }^{17}$

\footnotetext{
${ }^{1}$ Chinese Evidence-Based Medicine Centre, West China Hospital, Sichuan University, Chengdu 610041, Sichuan, China; ${ }^{2}$ First Teaching Hospital of Tianjin University of Traditional Chinese Medicine, Tianjin 300193, China; ${ }^{3}$ School of Medicine, Huzhou Teachers College, Huzhou 313000, Zhejiang, China; ${ }^{4}$ nnd Department of Internal Medicine, Jagiellonian University School of Medicine, Skawinska 8, 31-066 Krakow, Poland; ${ }^{5}$ Department of Clinical Epidemiology and Biostatistics, McMaster University, Hamilton, ON, Canada L8S 4K1; ${ }^{6}$ Department of Anesthesia, McMaster University, Hamilton, ON, Canada L8S 4K1; ${ }^{7}$ Michael G DeGroote Institute for Pain Research and Care, McMaster University, Hamilton, ON, Canada L8S 4K1; ${ }^{8}$ Stanford Prevention Research Centre, Department of Medicine, Stanford University, Stanford 94301, USA; ${ }^{9}$ Department of Anaesthesia and Pain Medicine, Hospital for Sick Children, Toronto, ON, Canada M5G 1X8; ${ }^{10}$ Norwegian Knowledge Centre for the Health Services, N-0130 Oslo, Norway; ${ }^{11}$ Department of Medicine, Innlandet Hospital Trust, 2819 Gjøvik, Norway; ${ }^{12}$ Internal Medicine Unit, Hospital Clinico FUSAT, Rancagua, Chile; ${ }^{13}$ Department of Medicine, Universidad Peruana Cayetano Heredia, Lima, Peru; ${ }^{14}$ Department of Medicine, University of British Columbia, Vancouver, BC, Canada V5Z 1M9; ${ }^{15}$ Population Genomics Program, McMaster University, Hamilton, ON, Canada L8S 4K1; ${ }^{16}$ Department of Medicine, McMaster University, Hamilton, ON, Canada L8S 4K1; ${ }^{17}$ Centre for Evidence-Based Medicine and Clinical Research, Taihe Hospital, Hubei University of Medicine, Shiyan 44200, Hubei, China
}

\begin{abstract}
Objective To investigate the risk of pancreatitis associated with the use of incretin-based treatments in patients with type 2 diabetes mellitus.

Design Systematic review and meta-analysis.

Data sources Medline, Embase, the Cochrane Central Register of Controlled Trials (CENTRAL), and ClinicalTrials.gov.

Eligibility criteria Randomised and non-randomised controlled clinical trials, prospective or retrospective cohort studies, and case-control studies of treatment with glucagon-like peptide-1 (GLP-1) receptor agonists or dipeptidyl peptidase-4 (DPP-4) inhibitors in adults with type 2 diabetes mellitus compared with placebo, lifestyle modification, or active anti-diabetic drugs.
\end{abstract}

Data collection and analysis Pairs of trained reviewers independently
screened for eligible studies, assessed risk of bias, and extracted data.
A modified Cochrane tool for randomised controlled trials and a modified
version of the Newcastle-Ottawa scale for observational studies were
used to assess bias. We pooled data from randomised controlled trials
using Peto odds ratios, and conducted four prespecified subgroup
analyses and a post hoc subgroup analysis. Because of variation in
outcome measures and forms of data, we describe the results of
observational studies without a pooled analysis.
Results 60 studies ( $\mathrm{n}=353639$ ), consisting of 55 randomised controlled
trials ( $\mathrm{n}=33$ 350) and five observational studies (three retrospective
cohort studies, and two case-control studies; $\mathrm{n}=320$ 289) were included.
Pooled estimates of 55 randomised controlled trials (at low or moderate

Correspondence to: X Sun, Chinese Evidence-Based Medicine Center, West China Hospital, Sichuan University, 37 Guo Xue Xiang, Chengdu 610041, Sichuan, China sunx26@gmail.com

Extra material supplied by the author (see http://www.bmj.com/content/348/bmj.g2366?tab=related\#webextra)

Appendix 1: Search strategies

Appendix 2: Characteristics, exposures, outcomes, results, and risk of bias of three excluded cohort studies

Appendix 3: Risk of bias of randomised controlled trials

Appendix 4: Supplementary forest plots 
risk of bias involving 37 pancreatitis events, raw event rate $0.11 \%$ ) did not suggest an increased risk of pancreatitis with incretins versus control (odds ratio $1.11,95 \%$ confidence interval 0.57 to 2.17 ). Estimates by type of incretin suggested similar results (1.05 (0.37 to 2.94) for GLP-1 agonists $v$ control; 1.06 ( 0.46 to 2.45 ) for DPP-4 inhibitors $v$ control).

Analyses according to the type of control, mode, duration of treatment, and individual incretin agents suggested no differential effect by subgroups, and sensitivity analyses by alternative statistical modelling and effect measures did not show important differences in effect estimates. Three retrospective cohort studies (moderate to high risk of bias, involving 1466 pancreatitis events, raw event rate $0.47 \%$ ) also did not suggest an increased risk of pancreatitis associated with either exenatide (adjusted odds ratios 0.93 (0.63 to 1.36) in one study and 0.9 (0.6 to 1.5) in another) or sitagliptin (adjusted hazard ratio $1.0,0.7$ to 1.3); a case-control study at moderate risk of bias (1003 cases, 4012 controls) also suggested no significant association (adjusted odds ratio $0.98,0.69$ to 1.38 ). Another case-control study (1269 cases, 1269 controls) at moderate risk of bias, however, suggested that the use of either exenatide or sitagliptin was associated with significantly increased odds of acute pancreatitis (use within two years $v$ no use, adjusted odds ratio $2.07,1.36$ to 3.13$)$.

Conclusions The available evidence suggests that the incidence of pancreatitis among patients using incretins is low and that the drugs do not increase the risk of pancreatitis. Current evidence, however, is not definitive, and more carefully designed and conducted observational studies are warranted to definitively establish the extent, if any, of increased risk.

\section{Introduction}

Acute pancreatitis is a serious condition that often leads to hospital admission and even death. Important risk factors for acute pancreatitis include gallstones, alcohol use, older age, black race, smoking, obesity, and type 2 diabetes. ${ }^{1}$ Exposure to certain drugs is also associated with acute pancreatitis. ${ }^{1}$ Glucagon-like peptide-1 (GLP-1) receptor agonists and dipeptidyl peptidase-4 (DPP-4) inhibitors are two classes of incretin based treatments for type 2 diabetes mellitus. Evidence from randomised controlled trials has shown that GLP-1 agonists effectively lower glycated haemoglobin (HbA1c) by about $1 \%,{ }^{2}$ reduce body weight, and rarely cause hypoglycaemia when used as monotherapy ${ }^{34}$; DDP-4 inhibitors have intermediate efficacy regarding glucose control ${ }^{5}$ with no impact on body weight and a low risk of hypoglycaemia. ${ }^{36}$ The American Diabetes Association (ADA) and the European Association for the Study of Diabetes (EASD) recommends the consideration of DPP-4 inhibitors and GLP agonists as second line treatment options. ${ }^{67}$

In 2008, the US Food and Drug Administration (FDA) warned of a strong temporal association between exenatide and pancreatitis on the basis of 30 case reports of acute pancreatitis. $^{8}$ In 2009, the FDA notified healthcare professionals and patients of revisions to the prescribing information for Januvia (sitagliptin) and Janumet (sitagliptin/metformin) after announcing the observation of 88 post-marketing cases of acute pancreatitis. ${ }^{9}$ In 2012 , one consumer group in the United States called for the withdrawal of liraglutide ${ }^{10}$ and cautioned that liraglutide is associated with higher than expected rates of pancreatitis, thyroid cancer, and kidney failure based on the following statement from FDA reviewers: "in clinical trials patients taking liraglutide had a risk of pancreatitis that was 3.7 fold higher than the risk in patients taking other antidiabetes drugs." In 2013, the concerns regarding the risk of pancreatitis and pancreatic cancer continued to grow, resulting in international debate. ${ }^{112}$ The $B M J$ has published several commentaries discussing the potential risk of pancreatitis and implications of using incretin based drugs. ${ }^{13-17}$ The FDA also has announced ongoing efforts to assess the risk of pancreatic associated with incretins. ${ }^{18}$ Yet the definitive recommendations regarding the risk are not available.

Findings from animal studies have been inconsistent. Some showed that exenatide seemed to increase inflammation of pancreatic acinar cells ${ }^{19}$ and formation of pancreatic intraepithelial neoplasia ${ }^{20}$; sitagliptin increased pancreatic ductal turnover and ductal metaplasia. ${ }^{21}$ Others suggested that exenatide improved chemically induced pancreatitis in normal and diabetic rodents $^{22}$ and that liraglutide induced cytokines with anti-inflammatory effects. ${ }^{23}$ Another study found that liraglutide did not induce pancreatitis in mice, rats, or monkeys when it was given for up to two years and at exposure concentrations up to 60 times higher than in used in humans. ${ }^{24}$

Results from drug safety surveillance systems have been more concerning. The evidence to support a causal relation between incretin based drugs and pancreatitis is weak. Most safety data have been acquired through the FDA adverse event reporting system (AERS), ${ }^{89}$ by which an appropriate selection of control and collection of information regarding the exposure and confounding factors is challenging. Because of ongoing safety concerns, there is a clear need for a rigorous evaluation of the safety of GLP-1 agonists and DPP-4 inhibitors. We conducted a systematic review of randomised and non-randomised studies to provide a comprehensive assessment regarding the risk of pancreatitis associated with GLP-1 agonists and DPP-4 inhibitors relative to placebo or active drugs.

\section{Methods Eligibility criteria}

We included randomised and non-randomised controlled trials, prospective and retrospective cohort studies, and case-control studies that enrolled adult patients with type 2 diabetes mellitus; included an unconfounded comparison of GLP-1 agonists or DPP-4 inhibitors against placebo, lifestyle modification, or active antidiabetic drugs; followed up patients for at least 12 weeks (not applicable for case-control studies); and explicitly reported event data on pancreatitis.

To be classified as an unconfounded comparison, we required that planned interventions were identical between treatment and control groups except the GLP-1 agonists or DDP-4 inhibitors under consideration. We also required that authors clearly and explicitly reported numbers of pancreatitis events in all treatment groups under consideration.

\section{Literature search}

We searched Medline, Embase, and the Cochrane Central Register of Controlled Trials (CENTRAL) up to March 2013 for published studies without language restrictions. We used both MeSH and free text terms to identify relevant articles. An information expert (DP) developed the search strategy (appendix 1). At the time of searching, we planned to investigate the effect of incretin treatments on people with and without on diabetes. We thus included search terms defining incretin drugs and study designs only.

We also searched ClinicalTrials.gov to identify additional eligible clinical trials. This trial registry documents all drug trials other than phase I studies as required by Section 801 of the US Food and Drug Administration Amendments Act (FDAAA 801) ${ }^{26}$ and typically includes extensive lists of adverse events. ${ }^{27}$ This provides important information regarding data on pancreatitis. We searched generic names of each individual drug to ensure high sensitivity. We undertook the search of 
ClinicalTrials.gov in August 2013 to ensure that data from previously published trials were updated on the registry. We limited our search to those trials labelled as "completed" and for which results were available.

\section{Study process}

We developed standardised pilot-tested forms together with detailed instructions for screening of abstracts and full text, risk of bias assessment, and data collection. Pairs of reviewers with training in research methods, independently and in duplicate, screened study reports for eligibility, assessed risk of bias, and collected data from each eligible study. Reviewers dealt with discrepancies through discussion or, if required, adjudication by a third reviewer (XS).

\section{Risk of bias assessment}

We used a modified version of Cochrane Collaboration's tool ${ }^{28}$ to assess the risk of bias of randomised controlled trials. We considered random sequence generation; allocation concealment; blinding of participants, caregivers, and outcome (that is, pancreatitis) assessors; adjudication of pancreatitis events; prognostic balance between treatment groups; and selective outcome reporting. In assessing the risk of bias with blinding, our modified instrument removed the "unclear" option for the assessment of blinding, an approach we have previously validated..$^{29}$

We used a modified version of the Newcastle-Ottawa quality assessment scale ${ }^{30}$ to assess the risk of bias in cohort and case-control studies. For cohort studies, we removed the item regarding representativeness of sample and the item "was the follow-up long enough?" as these items relate to applicability of results. For case-control studies, we also removed the item "representativeness of the cases." For both types of studies, we added two items, one dealing with ascertainment of type 2 diabetes and another with ascertaining confounding variables. We did not assess publication bias because of the low power associated with studies of rare events.

\section{Data collection}

From eligible randomised controlled trials we collected information on study characteristics (study design, sample size, number of treatment groups, length and design (such as variable or fixed) of follow-up, funding source, registry number, whether trials were international and, if so, countries involved, number of study sites, and study phase); patient characteristics (sex, age, duration of type 2 diabetes, baseline HbA1c concentrations, body mass index (BMI), and fasting plasma glucose);

interventions (drugs commonly used across all groups (baseline treatment), incretin treatment, control group, dose, intensity, and duration of treatment); pancreatitis events in each of the treatment groups; and number of patients included for analyses in each of the treatment groups (that is, considered as a safety set).

For extension randomised controlled trials, in which treatment assignments were switched (for example, patients in placebo group started receiving incretins), we documented only the outcome data before that point. For multiple reports of the same trial, we collated all data into a single study. ${ }^{31}$ If outcome data for pancreatitis were reported at multiple follow-up points, we used data from the longest follow-up.

For observational studies, we documented information as for randomised controlled trials, when applicable. Additionally, we collected information regarding study design (such as retrospective cohort study), sources of data (such as claims data), method of ascertaining type 2 diabetes status (such as ICD (international classification of diseases) code), exposures (such as incretins, and such exposure variables as age), method of adjustment for confounding (such as adjustment or matching, and variables used for these techniques), and follow-up. We also documented unadjusted and adjusted results, in addition to raw event data and exposure time.

\section{Data analysis}

We analysed randomised controlled trials and observational studies separately. For randomised trials, we assessed heterogeneity between studies using a $\chi^{2}$ test and the $\mathrm{I}^{2}$ statistic. We pooled trials using Peto's methods ${ }^{32}{ }^{33}$ and reported pooled Peto odds ratios and their associated $95 \%$ confidence intervals. $\mathrm{P}<0.05$ was considered significant. We explored sources of heterogeneity with four a priori subgroup hypotheses: type of incretin (GLP-1 agonists $v$ control; DPP-4 inhibitors $v$ control); type of control (incretin $v$ placebo, incretin $v$ active treatment); length of follow-up (incretin $v$ control by subgroup of $\leq 26$ weeks, 26-52 weeks, >52 weeks); and mode of treatment (incretin monotherapy $v$ control, incretin add-on/combination treatment $v$ control), and a post hoc subgroup analysis of different incretins. We undertook sensitivity analyses by using alternative effect measures (odds ratio $v$ relative risk), pooling methods (Peto methods $v$ Mantel-Haenszel method), and consideration on heterogeneity (random $v$ fixed effect).

We qualitatively analysed the data from observational studies because of differences in outcome measures, exposures (that is, drug under consideration), and forms of outcome data (that is, adjusted $v$ unadjusted data; hazard ratio $v$ incidence rate ratio). We reported the results according to meta-analysis of observational studies in epidemiology (MOOSE) ${ }^{34}$ and preferred reporting items for systematic reviews and meta-analyses (PRISMA). ${ }^{35}$

\section{Results}

Our search yielded 7432 potentially relevant reports. After screening titles and abstracts, we retrieved 468 reports for full text screening. Fifty nine studies, including 55 randomised controlled trials $^{36-90}$ ( 40 from journals and 15 from the trial registry) reported in 61 reports, three cohort studies, ${ }^{91-93}$ and one case-control study ${ }^{94}$ were eligible for inclusion (fig $1 \Downarrow$ ). Eight months after our formal search (November 2013), however, an additional large case-control study ${ }^{95}$ was published. We therefore also included this study, resulting in inclusion of two case-control studies. These studies recruited 353639 patients, including 33350 from randomised controlled trials and 320289 from observational studies. Three other retrospective cohort studies also examined risk of pancreatitis with incretin drugs ${ }^{96-98}$; they did not explicitly limit patients to those with type 2 diabetes mellitus and were therefore excluded (appendix 2).

\section{Evidence from randomised controlled trials}

The 55 randomised controlled trials - all industry funded-were conducted in 2-49 (median 11) countries and 3-268 (median 110) study sites; $45(82 \%)$ were international and $44(80 \%)$ were phase III studies. The length of follow-up ranged from 12 to 234 weeks. The trials enrolled 69 to 1615 patients (total 33 350 ), with a mean age range of 49.7-66.5, mean BMI range of 24.5-36.7, mean baseline HbA1c range of 7.3-9.8\%, mean fasting plasma glucose range of 7.7-11.3 $\mathrm{mmol} / \mathrm{L}$, and mean duration of diabetes range of 1-16.7 years (table $1 \Downarrow$ ). None of the studies explicitly mentioned their criteria for diagnosis of pancreatitis. 
Twenty seven randomised controlled trials tested GLP-1 receptor agonists, 26 tested DDP-4 inhibitors, and two tested both agents; 17 tested incretin monotherapy, and 38 used incretin agents as add-on or combination treatment (table $2 \Downarrow$ ). Duration of treatment ranged from 12-107 weeks (median 26; 22 trials longer than 26 weeks).

Thirty six randomised controlled trials $(66 \%)$ adequately generated random sequence, $33(60 \%)$ adequately concealed allocation (appendix 3); 47 (86\%) blinded patients, caregivers, and outcome assessors. None of the trials adjudicated pancreatitis events.

\section{Risk of pancreatitis in randomised trials}

Of the 55 randomised controlled trials reporting pancreatitis, 27 explicitly stated that no events of pancreatitis occurred during the course of study. Eight studies mentioned pancreatic enzymes; none, however, reported usable data. Overall, 37 pancreatitis events occurred in 33227 patients who used at least one drug (raw event rate $0.11 \%$ ). Results did not show a significant difference between incretins versus control (odds ratio 1.11, $95 \%$ confidence interval 0.57 to 2.17 ; fig $2 \Downarrow$ ).

When we explored the sources of heterogeneity, the risk did not differ by the type of incretin (GLP-1 agonists $v$ DPP- 4 inhibitors; interaction test $\mathrm{P}=0.99$ ): 29 trials, involving 14562 patients and 16 pancreatitis events $(0.11 \%)$ compared GLP- 1 agonists versus control (odds ratio $1.05,95 \%$ confidence interval 0.37 to 2.94 ); 28 trials, involving 19241 patients and 23 events (0.12\%) compared DPP-4 inhibitors versus control (1.06, 0.46 to 2.45). Neither analysis suggested an increased risk of pancreatitis (fig A in appendix 4).

The subgroup analysis by type of control (that is, placebo $v$ active drug) did not suggest apparent difference (odds ratio 1.27 in trials comparing with placebo, 1.00 in those comparing with active drug treatments; interaction $\mathrm{P}=0.72$ ) (fig $\mathrm{B}$ in appendix 4). Exploration of the effect by the mode of treatment (monotherapy $v$ add-on/combination treatment) also did not suggest significant difference ( 0.84 monotherapy $v 1.22$ add-on/combination treatment; interaction $\mathrm{P}=0.63$ ) (fig $\mathrm{C}$ in appendix 4). Nor was there a difference by length of follow-up (interaction $\mathrm{P}=0.84$; odds ratio 0.90 at 26 weeks or shorter $v$ 1.44 at 26-52 weeks $v 1.14$ over 52 weeks) (fig D in appendix 4). The post hoc analysis of individual incretins did not show difference among those agents (fig E in appendix 4).

The sensitivity analysis using alternative effect measures (relative risk $v$ odds ratio), statistical models (Mantel-Haenszel $v$ Peto) and considerations on heterogeneity (random effect $v$ fixed effect) did not show important change in the pooled effects (figs F-H in appendix 4).

\section{Evidence from observational studies}

Of the five observational studies, three retrospective cohort studies examined the risk of acute pancreatitis associated with the use of exenatide, sitagliptin, or both, ${ }^{91-93}$ and two case-control studies specifically assessed the risk of admission to hospital for acute pancreatitis in patients with type 2 diabetes taking incretins ${ }^{94} 95$ (tables $3 \Downarrow$ and $4 \Downarrow$ ).

Of the three cohort studies, the first included 38615 patients with diabetes (6545 exenatide, 15826 sitagliptin, and 16244 control) recruited in the US Medco National Integrated Database. ${ }^{91}$ Patients aged 18-63 were identified with ICD-9 code for drugs for type 2 diabetes and were followed up for a mean of 0.7 year ( 0.6 exenatide, 0.8 sitagliptin, 0.7 control). Exposure to incretins was probably identified from pharmacy claims.
Study investigators computed a chronic disease score based on pharmacy claims data and identified risk factors for pancreatitis, including drugs and medical conditions by using pharmacy claims and ICD-9 codes. Acute pancreatitis was identified with ICD-9 codes; 154 pancreatitis events $(0.4 \%)$ occurred (22 in the exenatide group $(0.3 \%), 67$ in the sitagliptin group $(0.4 \%)$, 65 in the control group $(0.4 \%)$ ), with a corresponding incidence of 563.9 cases per 100000 patient years (569.9 in the exenatide group, 554.4 in the sitagliptin group, and 571.9 in the control group). After adjustment for the influence of age, sex, history of pancreatic disease, alcohol intake, biliary stone disease, hypertriglyceridaemia, and chronic disease score, the risk of acute pancreatitis was similar between exenatide and control (adjusted hazard ratio 0.9, 95\% confidence interval 0.6 to 1.5 ) and sitagliptin and control (1.0, 0.7 to 1.3$)$.

The second study included 268561 patients (530 574 patient years, 13791 patient years in exenatide group, 516783 non-exenatide) with type 2 diabetes from an employer-provided health insurance covering about 6.6 million employees in the US. ${ }^{92}$ Patients were aged 63.1 on average, with mean duration of diabetes of 3.1 years. Study investigators used ICD-9 codes to identify patients with type 2 diabetes and their pancreatic outcome (admission for acute pancreatitis, code 577.0). The information regarding exposure to exenatide was identified by National Drug Codes. They also used ICD-9 codes to identify information regarding a set of 19 co-morbid conditions (such as congestive heart failure, chronic obstructive pulmonary disease, and stroke) and traditional risk factors for pancreatitis. They identified $1312(0.5 \%)$ admissions for acute pancreatitis events (27 in those taking exenatide, 1285 in those not taking exenatide), with corresponding incidence of 247.3 cases per 100000 patient years (195.8 for exenatide, 248.7 for non-exenatide). The risk of admission for acute pancreatitis in patients who have used exenatide was not statistically different $(0.20 \% v 0.25 \%$; adjusted odds ratio $0.93,95 \%$ confidence interval 0.63 to 1.36 ) after adjustment for age, sex, years since diagnosis of diabetes, year of observation, 19 co-morbid conditions, and traditional risk factors for pancreatitis.

The third study recruited 5560 patients from a diabetes specialty care centre in India. ${ }^{93}$ Of these patients, 2817 received sitagliptin and 2743 self injected insulin glargine. Information regarding ascertainment of other variables (confounders), however, was not reported. This study found no patient with either symptoms or signs of acute pancreatitis in the sitagliptin or insulin glargine group.

The first case-control study identified 1269 cases (admissions for acute pancreatitis) and 1269 controls from administrative claims of Blue Cross Blue Shield plan. ${ }^{94}$ All of these patients, aged 52 on average, had type 2 diabetes, as confirmed by ICD-9 codes or drug history for hyperglycaemia. Patients with type 1 diabetes or gestational diabetes were excluded. Cases were identified with a validated algorithm based on ICD-9 and current procedural terminology codes for acute pancreatitis, and occurrences of pancreatitis within three months of enrolment were excluded. Controls were selected, on a 1:1 ratio, for each case; they were matched for age within 10 years, sex, insurance plan site, diabetes complication severity index, and enrolment pattern or duration of follow-up. Information on drug exposure (exenatide or sitagliptin) was identified from the pharmacy database. No information was available regarding the ascertainment of risk factors for acute pancreatitis and use of other drugs. After we controlled for the influence of hypertriglyceridaemia, alcohol use, gallstones, tobacco abuse, obesity, biliary and pancreatic cancer, cystic fibrosis, an indicator of general morbidity level, and metformin exposure 
during the same period, we found that use of sitagliptin or exenatide within 30 days before pancreatitis versus non-use (that is, no use for more than two years before the index date of pancreatitis event; adjusted odds ratio $2.24,95 \%$ confidence interval 1.36 to 3.68 ), recent use (30 days to two years before admission; $2.01,1.37$ to 3.18 ), and any use within two years (2.07, 1.36 to 3.13$)$ were associated with significantly increased odds of acute pancreatitis.

The second case-control study, conducted in Italy, assessed the use of incretins (exenatide, liraglutide, sitagliptin, saxagliptin, and vildagliptin) ${ }^{95}$ This study identified 1003 cases (admission for acute pancreatitis) and 4012 controls matched for year of birth, sex, and year of first exposure to antidiabetic drugs from regional administrative data of the Italian national health system that allowed the linkage of drugs dispensed with hospital discharges. All the patients with type 2 diabetes, dispensed at least one dose of antidiabetic drugs and aged 72 on average, were identified according to the ICD-9 system. Patients coded for type 1 diabetes $(250 . x 1,250 . x 3)$ were excluded. Cases were identified through the ICD-9 code (577.0) at discharge. The exposure to incretins and other antidiabetic drugs (metformin or glibenclamide) was measured according to the anatomical therapeutic classification system. Potential confounders-history of chronic or acute pancreatitis, gallstones, alcohol misuses, biliary tract or pancreatic cancers, and admission for cardiovascular diseases and diabetic retinopathy-were measured with ICD-9 codes. After adjustment for those confounders and the use of other antidiabetic drugs, the adjusted analyses did not show a significant association between the exposure to incretins and the risk of admission for acute pancreatitis (adjusted odds ratio $0.98,95 \%$ confidence interval 0.69 to 1.38 )

\section{Risk of bias in observational studies}

All observational studies used either claims data or patients' medical records for their analyses. Studies using claims data or medical records confirmed diagnosis of type 2 diabetes, drug exposures, confounding factors, and occurrence of pancreatitis based on ICD-9 codes and pharmacy claims data (tables 5 and $6 \Downarrow \Downarrow)$. The approaches for ascertaining type 2 diabetes differed across those studies (the ICD-9 codes they used varied), and the accuracy of ascertaining type 2 diabetes remains unclear. Three studies described the method for ascertaining confounding factors and the use of drugs other than incretins. ${ }^{91} 9295$ Though the four studies that used claims data adjusted for the association, they chose different variables, leaving the adequacy of adjustment questionable. All studies failed to report the extent to which the claims data were complete in the overall database. Because of these limitations the risk of bias associated with eligible observational data was moderate to high.

\section{Discussion \\ Main findings}

In this systematic review and analysis of 55 randomised trials (low to moderate risk of bias involving 37 cases of pancreatitis among 33227 patients), three retrospective cohort studies (moderate to high risk of bias involving 1466 pancreatitis events among 312736 patients), and one case-control study (moderate risk of bias involving 1003 patients admitted to hospital for acute pancreatitis) we found no evidence to suggest an increased risk of pancreatitis associated with the use of incretins in patients with type 2 diabetes. The other case-control study (1269 patients admitted for acute pancreatitis), at moderate risk of bias, reported increased risk of admission for pancreatitis associated with the use of sitagliptin or exenatide.

The incidence of pancreatitis was low. In randomised trials, pancreatitis occurred in $0.11 \%$ of patients $(0.11 \%$ in those taking incretins; $0.11 \%$ in control patients). In cohort studies, the risk of acute pancreatitis and admission for pancreatitis was higher $(0.47 \%)$ than the risk in randomised trials, potentially because of a higher incidence of risk factors such as gallstones and longer follow-up.

Our findings should be interpreted cautiously. Although we included a large number of randomised trials, those trials were typically designed for testing efficacy. Many had relatively small sample sizes and relatively short follow-up. Because pancreatitis is rare and the event rates low, the confidence intervals around relative effects are wide, leaving the possibility of an undetected increase in risk. Furthermore, these trials-mostly phase III studies-often recruited patients with less co-morbidity than patients seen in clinical practice. The risk in the non-exposed patient group is therefore lower than usual (as above $0.11 \%$ in trials $v 0.47 \%$ in observational studies). This in part explains the wide confidence intervals and also limits generalisability of the results.

There are further potential limitations of the randomised trials. Trials could have failed to document pancreatitis events or, if documented, failed to report these events (that is, selective reporting bias). Pancreatitis, however, is usually considered a serious adverse event in trials of type 2 diabetes, and, according to FDA's policy, the reporting of serious adverse event data is mandatory to ClinicalTrials.gov, ${ }^{27}$ limiting the risk of lack of monitoring and selective reporting. Even if pancreatitis events were monitored, however, they might not have been independently adjudicated, raising the possibility of inaccurate data.

A final issue is the possibility of failure to identify patients with subclinical minimally symptomatic pancreatitis. The increase of pancreatic enzyme activity (lipase and amylase), a surrogate measure, could represent supporting evidence in the assessment of the risk of pancreatitis; these data, however, were not readily usable.

The five observational studies, involving patients in real practice, had large sample sizes, but had limitations related to use of claims data or patients' medical records. Because most studies relied on the ICD-9 coding system to identify study populations and outcomes, the ascertainment of type 2 diabetes, and particularly pancreatitis, was probably inadequate because of the variation of diagnosis criteria and lack of outcome adjudication. Similar to the situation with trials, subclinical and minimally symptomatic cases of pancreatitis were less likely to be identified in those studies. Additionally, the exposure to incretins and control drugs and the exposure to other confounding factors might not have been accurately documented. The completeness of data within each of those databases is also unclear; investigators might have excluded those without complete exposure and outcome data from analyses. Finally, the accurate measurement and adjustment for other prognostic factors was limited. Overall, the risk of bias was moderate to high in all observational studies.

Among those five observational studies, a single case-control study suggested an increased risk of admissions for acute pancreatitis; the four others, including three cohort studies and one case-control study, did not. Of the four studies suggesting no increased risk, three consistently reported the point estimates close to 1 and the confidence intervals were similar (0.6 to 1.5$)$. The reasons for discrepancy between the single case-control 
study and the other studies are not clear: the selection of different study populations (that is, different age groups, thus differing baseline risk) and different choices of exposures and non-exposures are possible explanations. Varying risk of bias and inadequate control of confounders are other explanations.

In addition to those five eligible observational studies, three retrospective cohort studies (appendix 2), at moderate risk of bias and that failed to limit patients to those with type 2 diabetes (and were therefore excluded), reported the risk of acute pancreatitis associated with exenatide. ${ }^{96-98}$ These studies consistently suggested that exenatide was not associated with an increased risk of acute pancreatitis.

The FDA adverse drug event system has documented 2327 spontaneously reported cases of pancreatitis in patients taking exenatide, 888 case in those taking liraglutide, 718 cases in those taking sitagliptin, and 125 cases in those taking saxagliptin. ${ }^{12}$ The number of cases of pancreatitis seemed larger in those taking incretins than other active antidiabetic drugs, suggesting a potentially increased risk. The absence of data on number of patients exposed to those antidiabetic drugs, and the possibility of a lower threshold of reporting with new drugs, however, severely limits the usefulness of these data for making causal inferences.

\section{Strengths and limitations}

Our study has several strengths. Firstly, we systematically identified and included both randomised and non-randomised studies to examine the risk of pancreatitis associated with incretin treatment. Secondly, in addition to published reports, we searched ClinicalTrials.gov, which provided additional outcome information and eligible trials. Thirdly, we instituted a rigorous approach to ensure the data were accurate, in particular using the data on pancreatitis reported in ClincialTrials.gov and journal publications for consistency.

We did not assess the risk of pancreatic cancer associated with the use of incretins. Although studies have suggested a potentially increased risk, they have many limitations. ${ }^{99}$ The FDA adverse drug event system documented 258 cases of pancreatic cancer in patients taking exenatide, 63 cases in those taking liraglutide, 81 cases in those taking sitagliptin, and 18 cases in those taking saxagliptin. ${ }^{12}$ The number of cancer cases did not seem larger in patients taking incretins (except exenatide) than other drugs for diabetes. We also did not specifically assess the risk of chronic pancreatitis associated with the use of incretins; few data on this issue are available.

\section{Comparison with other studies}

Two other meta-analyses have assessed the risk of pancreatitis among patients using incretins, one examining GLP-1 agonists ${ }^{100}$ and another DPP-4 inhibitors. ${ }^{101}$ The first meta-analysis, involving 22 randomised controlled trials and three retrospective cohort studies, reported no significant association between pancreatitis events and the exposure to exenatide or liraglutide. ${ }^{100}$ This analysis pooled results of randomised trials and large observational studies, making the interpretation of estimates challenging: in 10 randomised controlled trials and three retrospective cohort studies the odds ratio for exenatide was 0.84 (95\% confidence interval 0.58 to 1.22 ) and in the combined results of 10 randomised controlled trials the odds ratio for liraglutide was 0.97 (0.21 to 4.39). Furthermore, this study included two cohort studies, in which patients might not be strictly limited to those with type 2 diabetes mellitus and were thus excluded from our review. The second study was a meta-analysis of exclusively randomised controlled trials, investigated risk of pancreatitis in DDP-4 inhibitors. ${ }^{101}$ It found that DPP-4 inhibitors were not associated with an increased risk of pancreatitis (odds ratio $0.93,95 \%$ confidence interval 0.51 to 1.69$).{ }^{101}$ Both meta-analyses included trials that had no explicit information regarding pancreatitis; they might have assumed that no pancreatitis occurred in such trials. It is probably reasonable to assume no event in the absence of reporting in such situation. This approach, however, could artificially reduce the incidence of pancreatitis as more patients are added to the population whereas no events are added. In either of the approaches (ours and those of the two other published meta-analyses), however, the statistical model did not include zero event trials in meta-analyses, as they are statistically omitted in pooling relative effects. Compared with these two meta-analyses, our study included five observational studies that carry more important information regarding the risk of pancreatitis.

\section{Conclusion}

In summary, the available evidence suggests that the incidence of pancreatitis in patients taking incretins is low and that these drugs do not increase the risk of pancreatitis. The current body evidence, however, is not definitive, and more carefully designed and conducted observational studies are warranted to definitively establish the extent, if any, of increased risk. In addition, incretins, which are expensive, are no superior to widely used antidiabetic drugs (such as metformin) for glucose control. Given the uncertainty about the effect of incretins on important outcomes, including pancreatitis, the lack of apparent benefits in glucose control over other drugs, and the relatively high costs, the use of incretins might not be preferable to other available antidiabetic drugs.

Future demonstration of consistency of the putative association across studies is warranted. Trialists exploring the effect of incretins should report all adverse events affecting the pancreas. Presentation of associations both in class of agents (such as GLP-1 agonists) and individual incretins is important and informative to assess the potential risk. Reporting of results for the gradient of pancreatic outcomes-pancreatic enzymes, asymptomatic pancreatitis, symptomatic pancreatitis, and admission for acute pancreatitis-will also be helpful for informing risks associated with incretin treatment. Future randomised trials that specifically examine this issue, however, are unlikely. We need more carefully designed and conducted observational studies that clearly define study population, accurately collect information regarding length to follow exposure and confounding factors, completely collect outcome data, and adequately adjust for the influence of confounders. Currently, a European study is applying surveillance and observational study methods to assess vascular and pancreatic safety of diabetes drugs, including thiazolidinedones (TZDs), incretins, and amylin analogues in people with type 2 diabetes. ${ }^{102}$ The resulting findings might provide more definitive evidence.

We thank Daphne Plaut for developing the search strategy and conducting literature search and Stephen D Walter for useful advice in data analysis.

Contributors: XS conceived the study and acquired the funding. XS and LL had full access to all of the data in the study, and take responsibility for the integrity of the data and the accuracy of the data analysis. XS, LL, GHG, SJT, MMB, POV, LPR, and GM designed the study. XS and LL developed and tested the data collection forms. LL, JTS, MMB, JWB, SE, POV, LPR, GM, EW, ZS and XS acquired the data. LL and XS conducted the analysis and interpreted the data. XS and LL drafted the manuscript. All authors critically revised the manuscript. XS is guarantor. 


\section{What is already known on this topic}

A number of cases of acute pancreatitis have been reported in patients with type 2 diabetes who were taking incretins

Concerns have arisen regarding the risk of pancreatitis associated with these agents, though findings from various studies are conflicting

\section{What this study adds}

Data from randomised controlled trials are not adequate to assess the risk of pancreatitis, but several large observational studies, with methodological limitations, provide relatively precise estimates

The available evidence suggests that the incidence of pancreatitis in patients with type 2 diabetes taking incretins is low and that incretins do not increase risk of pancreatitis

Funding: This study was funded by Young Investigator Award, Sichuan University (project No 2013SCU04A37). JWB is funded by a New Investigator Award from the Canadian Institutes of Health Research and Canadian Chiropractic Research Foundation. SE is funded by MITACS Elevate and Restracomp Postdoctoral Awards. The funders had no role in the study design, writing of the manuscript, or decision to submit this or future manuscripts for publication.

Competing interests: All authors have completed the ICMJE uniform disclosure form at http://www.icmje.org/coi_disclosure.pdf and declare: no support from any organisation for the submitted work; no financial relationships with any organisations that might have an interest in the submitted work in the previous three years, no other relationships or activities that could appear to have influenced the submitted work.

Ethical approval: Not required.

Transparency: The lead author (the manuscript's guarantor) affirms that the manuscript is an honest, accurate, and transparent account of the study being reported; that no important aspects of the study have been omitted; and that any discrepancies from the study as planned have been explained.

Data sharing: No additional data available.

Yadav D, Lowenfels AB. The epidemiology of pancreatitis and pancreatic cancer. Gastroenterology 2013;144:1252-61.

2 Aroda VR, Henry RR, Han J, Huang W, DeYoung MB, Darsow T, et al. Efficacy of GLP-1 receptor agonists and DPP-4 inhibitors: meta-analysis and systematic review. Clin Ther 2012;34:1247-58.e22

3 Ismail-Beigi F. Glycemic management of type 2 diabetes mellitus. N Engl J Med 2012;366:1319-27.

4 Vilsboll T, Christensen M, Junker AE, Knop FK, Gluud LL. Effects of glucagon-like peptide-1 receptor agonists on weight loss: systematic review and meta-analyses of randomised controlled trials. BMJ 2012;344:d7771.

5 Karagiannis T, Paschos P, Paletas K, Matthews DR, Tsapas A. Dipeptidyl peptidase-4 inhibitors for treatment of type 2 diabetes mellitus in the clinical setting: systematic review and meta-analysis. BMJ 2012;344:e1369.

6 Inzucchi SE, Bergenstal RM, Buse JB, Diamant M, Ferrannini E, Nauck M, et al. Management of hyperglycemia in type 2 diabetes: a patient-centered approach: position statement of the American Diabetes Association (ADA) and the European Association for the Study of Diabetes (EASD). Diabetes Care 2012;35:1364-79.

7 American Diabetes Association. Standards of medical care in diabetes-2014. Diabetes Care 2014;37:S14-80

8 US Food and Drug Administration. Exenatide (marketed as BYETTA): acute pancreatitis. www.fda.gov/Drugs/DrugSafety/DrugSafetyNewsletter/ucm119034.htm\#exenatide.

9 US Food and Drug Administration. Sitagliptin (marketed as Januvia and Janumet)—acute pancreatitis. www.fda.gov/Safety/MedWatch/Safetylnformation/ SafetyAlertsforHumanMedicalProducts/ucm 183800.htm

10 Lenzer J. Consumer group calls for antidiabetes drug to be withdrawn. $B M$ 2012:344:e3259.

11 Nauck MA. A critical analysis of the clinical use of incretin-based therapies: the benefits by far outweigh the potential risks. Diabetes Care 2013;36:2126-32.

12 Butler PC, Elashoff M, Elashoff R, Gale EA. A critical analysis of the clinical use of incretin-based therapies: are the GLP-1 therapies safe? Diabetes Care 2013;36:2118-25.

13 Gale E. Incretin therapy: should adverse consequences have been anticipated? BMJ 2013;346:f3617

14 Cohen D. Has pancreatic damage from glucagon suppressing diabetes drugs been underplayed? BMJ 2013;346:\{3680.

15 Kmietowicz Z. Potential harms of type 2 diabetes drugs have been ignored, finds BMJ investigation. BMJ 2013;346:f3782.

16 Cohen D. Pressure mounts for companies to hand over data on antidiabetes drugs linked to pancreatic harm. BMJ 2013;346:f3900.

17 Cohen D. European drugs agency clashes with scientists over safety of GLP-1 drugs. BMJ 2013;347:44838.

18 US Food and Drug Administration. Incretin mimetic drugs for type 2 diabetes: early communication-reports of possible increased risk of pancreatitis and pre-cancerous findings of the pancreas. www.fda.gov/Safety/MedWatch/Safetylnformation/ SafetyAlertsforHumanMedicalProducts/ucm343805.htm.

19 Nachnani JS, Bulchandani DG, Nookala A, Herndon B, Molteni A, Pandya P, et al. Biochemical and histological effects of exendin-4 (exenatide) on the rat pancreas. Diabetologia 2010;53:153-9.
20 Gier B, Matveyenko AV, Kirakossian D, Dawson D, Dry SM, Butler PC. Chronic GLP-1 receptor activation by exendin- 4 induces expansion of pancreatic duct glands in rats and accelerates formation of dysplastic lesions and chronic pancreatitis in the $\operatorname{Kras}(\mathrm{G} 12 \mathrm{D})$ mouse model. Diabetes 2012;61:1250-62.

21 Matveyenko AV, Dry S, Cox HI, Moshtaghian A, Gurlo T, Galasso R, et al. Beneficial endocrine but adverse exocrine effects of sitagliptin in the human islet amyloid polypeptide transgenic rat model of type 2 diabetes: interactions with metformin. Diabetes 2009;58:1604-15

22 Tatarkiewicz K, Smith PA, Sablan EJ, Polizzi CJ, Aumann DE, Villescaz C, et al. Exenatide does not evoke pancreatitis and attenuates chemically induced pancreatitis in normal and diabetic rodents. Am J Physiol Endocrinol Metab 2010;299:E1076-86.

23 Koehler JA, Baggio LL, Lamont BJ, Ali S, Drucker DJ. Glucagon-like peptide-1 receptor activation modulates pancreatitis-associated gene expression but does not modify the susceptibility to experimental pancreatitis in mice. Diabetes 2009;58:2148-61.

24 Nyborg NC, Molck AM, Madsen LW, Knudsen LB. The human GLP-1 analog liraglutide and the pancreas: evidence for the absence of structural pancreatic changes in three species. Diabetes 2012;61:1243-9.

25 Elashoff M, Matveyenko AV, Gier B, Elashoff R, Butler PC. Pancreatitis, pancreatic, and thyroid cancer with glucagon-like peptide-1 based therapies. Gastroenterology 2011;141:150-6.

26 ClinicalTrials.gov. Why should I register and submit results? www.clinicaltrials.gov/ct2/ manage-recs/background.

27 US Food and Drug Administration. Food and Drug Administration Amendments Act (FDAAA) of 2007. US Public Law 110-85 section 801. www.gpo.gov/fdsys/pkg/PLAW110publ85/pdf/PLAW-110publ85.pdf.

28 Higgins JPT AD, Sterne JAC. Assessing risk of bias in included studies. In: Higgins JPT, Green S, eds. Cochrane handbook for systematic reviews of interventions. Version 5.1.0. Cochrane Collaboration, 2011

29 Akl EA, Sun X, Busse JW, Johnston BC, Briel M, Mulla S, et al. Specific instructions for estimating unclearly reported blinding status in randomized trials were reliable and valid. Clin Epidemiol 2012;65:262-7.

30 Wells GA SB, O'Connell D, Peterson J, Welch V, Losos M, et al. The Newcastle-Ottawa Scale (NOS) for assessing the quality of non-randomized studies in meta-analysis. www. ohri.ca/programs/clinical_epidemiology/oxford.asp.

31 Higgins JPT, Green S, eds. Cochrane handbook for systematic reviews of interventions. Version 5.1.0. Cochrane Collaboration, 2011.

32 Bradburn MJ, Deeks JJ, Berlin JA, Russell Localio A. Much ado about nothing: a comparison of the performance of meta-analytical methods with rare events. Stat Med 2007;26:53-77.

33 Higgins JPT Deeks JJ, Altman DG. Special topics in statistics. In: Higgins JPT, Green S, eds. Cochrane handbook for systematic reviews of interventions. Version 5.1.0. Cochrane Collaboration, 2011

34 Stroup DF, Berlin JA, Morton SC, Olkin I, Williamson GD, Rennie D, et al. Meta-analysis of observational studies in epidemiology: a proposal for reporting. Meta-analysis of observational studies in epidemiology (MOOSE) group. JAMA 2000;283:2008-12.

35 Moher D, Liberati A, Tetzlaff J, Altman DG. Preferred reporting items for systematic reviews and meta-analyses: the PRISMA statement. BMJ 2009;339:b2535.

36 Araki E, Kawamori R, Inagaki N, Watada H, Hayashi N, Horie $\mathrm{Y}$, et al. Long-term safety of linagliptin monotherapy in Japanese patients with type 2 diabetes. Diabetes Obes Metab 2013:15:364-71.

37 Barnett AH, Patel S, Harper R, Toorawa R, Thiemann S, von Eynatten M, et al. Linagliptin monotherapy in type 2 diabetes patients for whom metformin is inappropriate: an 18-week randomized, double-blind, placebo-controlled phase III trial with a 34-week active-controlled extension. Diabetes Obes Metab 2012;14:1145-54.

38 Bergenstal RM, Wysham C, MacConell L, Malloy J, Walsh B, Yan P, et al. Efficacy and safety of exenatide once weekly versus sitagliptin or pioglitazone as an adjunct to metformin for treatment of type 2 diabetes (DURATION-2): a randomised trial. Lancet 2010;376:431-9.

39 Bunck MC, Diamant M, Corner A, Eliasson B, Malloy JL, Shaginian RM, et al. One-year treatment with exenatide improves (beta)-cell function, compared with insulin glargine, in metformin-treated type 2 diabetic patients: a randomized, controlled trial. Diabetes Care 2009;32:762-8.

40 Buse JB, Bergenstal RM, Glass LC, Heilmann CR, Lewis MS, Kwan AY, et al. Use of twice-daily exenatide in Basal insulin-treated patients with type 2 diabetes: a randomized controlled trial. Ann Intern Med 2011;154:103-12.

41 Chacra AR, Tan GH, Ravichandran S, List J, Chen R; CV181040 Investigators. Safety and efficacy of saxagliptin in combination with submaximal sulphonylurea versus up-titrated sulphonylurea over 76 weeks. Diab Vasc Dis Res 2011;8:150-9.

42 Diamant M, Van Gaal L, Stranks S, Northrup J, Cao D, Taylor K, et al. Once weekly exenatide compared with insulin glargine titrated to target in patients with type 2 diabetes (DURATION-3): an open-label randomised trial. Lancet 2010;375:2234-43.

43 Fonseca VA, Alvarado-Ruiz R, Raccah D, Boka G, Miossec P, Gerich JE. Efficacy and safety of the once-daily GLP-1 receptor agonist lixisenatide in monotherapy: a randomized, double-blind, placebo-controlled trial in patients with type 2 diabetes (GetGoal-Mono). Diabetes Care 2012;35:1225-31.

44 Gallwitz B, Rosenstock J, Rauch T, Bhattacharya S, Patel S, von Eynatten M, et al. 2-year efficacy and safety of linagliptin compared with glimepiride in patients with type 2 diabetes inadequately controlled on metformin: a randomised, double-blind, non-inferiority trial. Lancet 2012;380:475-83. 
45 Gallwitz B, Guzman J, Dotta F, Guerci B, Simo R, Basson BR, et al. Exenatide twice daily versus glimepiride for prevention of glycaemic deterioration in patients with type 2 diabetes with metformin failure (EUREXA): an open-label, randomised controlled trial. Lancet 2012;379:2270-8

46 Garber A, Henry R, Ratner R, Garcia-Hernandez PA, Rodriguez-Pattzi H, Olvera-Alvarez I, et al. Liraglutide versus glimepiride monotherapy for type 2 diabetes (LEAD-3 Mono): a randomised, 52-week, phase III, double-blind, parallel-treatment trial. Lancet 2009;373:473-81.

47 Grunberger G, Chang A, Garcia Soria G, Botros FT, Bsharat R, Milicevic Z. Monotherapy with the once-weekly GLP-1 analogue dulaglutide for 12 weeks in patients with type 2 diabetes: dose-dependent effects on glycaemic control in a randomized, double-blind placebo-controlled study. Diabet Med 2012;29:1260-7.

48 Haak T, Meinicke T, Jones R, Weber S, von Eynatten M, Woerle HJ. Initial combination of linagliptin and metformin improves glycaemic control in type 2 diabetes: a randomized, double-blind, placebo-controlled study. Diabetes Obes Metab 2012;14:565-74.

49 Henry RR, Mudaliar S, Kanitra L, Woloschak M, Balena R; T-Emerge 3 Study Group. Efficacy and safety of taspoglutide in patients with type 2 diabetes inadequately controlled with metformin plus pioglitazone over 24 weeks: T-Emerge 3 trial. J Clin Endocrinol Metab 2012;97:2370-9.

50 Hollander PL, Li J, Frederich R, Allen E, Chen R; CV181013 Investigators. Safety and efficacy of saxagliptin added to thiazolidinedione over 76 weeks in patients with type 2 diabetes mellitus. Diab Vasc Dis Res 2011;8:125-35.

51 Hollander P, Lasko B, Barnett AH, Bengus M, Kanitra L, Pi-Sunyer FX, et al. Effects of taspoglutide on glycemic control and body weight in obese patients with type 2 diabetes (T-emerge 7 study). Obesity (Silver Spring) 2013;21:238-47.

52 Inagaki $\mathrm{N}$, Atsumi $\mathrm{Y}$, Oura $\mathrm{T}$, Saito $\mathrm{H}$, Imaoka $\mathrm{T}$. Efficacy and safety profile of exenatide once weekly compared with insulin once daily in Japanese patients with type 2 diabetes treated with oral antidiabetes drug(s): results from a 26-week, randomized, open-label, parallel-group, multicenter, noninferiority study. Clin Ther 2012;34:1892-908 e1.

53 Kadowaki T, Namba M, Yamamura A, Sowa H, Wolka AM, Brodows RG. Exenatide exhibits dose-dependent effects on glycemic control over 12 weeks in Japanese patients with suboptimally controlled type 2 diabetes. Endocr J 2009:56:415-24.

54 Kaku K, Rasmussen MF, Clauson P, Seino Y. Improved glycaemic control with minimal hypoglycaemia and no weight change with the once-daily human glucagon-like peptide-1 analogue liraglutide as add-on to sulphonylurea in Japanese patients with type 2 diabetes. Diabetes Obes Metab 2010;12:341-7.

55 Kikuchi M, Haneda M, Koya D, Tobe K, Onishi Y, Couturier A, et al. Efficacy and tolerability of vildagliptin as an add-on to glimepiride in Japanese patients with type 2 diabetes mellitus. Diabetes Res Clin Pract 2010;89:216-23.

56 Kothny W, Shao Q, Groop PH, Lukashevich V. One-year safety, tolerability and efficacy of vildagliptin in patients with type 2 diabetes and moderate or severe renal impairment. Diabetes Obes Metab 2012;14:1032-9.

57 Marre M, Shaw J, Brandle M, Bebakar WM, Kamaruddin NA, Strand J, et al. Liraglutide, a once-daily human GLP-1 analogue, added to a sulphonylurea over 26 weeks produces greater improvements in glycaemic and weight control compared with adding rosiglitazone or placebo in subjects with type 2 diabetes (LEAD-1 SU). Diabet Med 2009;26:268-78.

58 Nauck MA, Ratner RE, Kapitza C, Berria R, Boldrin M, Balena R. Treatment with the human once-weekly glucagon-like peptide-1 analog taspoglutide in combination with metformin improves glycemic control and lowers body weight in patients with type 2 diabetes inadequately controlled with metformin alone: a double-blind placebo-controlled study. Diabetes Care 2009;32:1237-43.

59 Nauck M, Horton E, Andjelkovic M, Ampudia-Blasco FJ, Parusel CT, Boldrin M, et al. Taspoglutide, a once-weekly glucagon-like peptide 1 analogue, vs. insulin glargine titrated to target in patients with type 2 diabetes: an open-label randomized trial. Diabet Med 2013;30:109-13.

60 Nauck M, Frid A, Hermansen K, Thomsen AB, During M, Shah N, et al. Long-term efficacy and safety comparison of liraglutide, glimepiride and placebo, all in combination with metformin in type 2 diabetes: 2-year results from the LEAD-2 study. Diabetes Obes Metab 2013;15:204-12.

61 Amylin Pharmaceuticals, LLC. Effect of AC2993 compared with insulin glargine in patients with type 2 diabetes also using combination therapy with sulfonylurea and metformin. National Library of Medicine (US), 2000. http://clinicaltrials.gov/show/NCT00082381.

62 Merck. An investigational drug study in patients with type 2 diabetes mellitus. National Library of Medicine (US), 2000. http://clinicaltrials.gov/show/NCT00094770.

63 Merck. MK0431 (sitagliptin) and metformin co-administration factorial study in patients with type 2 diabetes mellitus. National Library of Medicine (US), 2000. http://clinicaltrials. gov/show/NCT00103857.

64 Bristol-Myers Squibb. A phase 3 study of BMS-477118 in combination with metformin in subjects with type 2 diabetes who are not controlled with diet and exercise. National Library of Medicine (US), 2000. http://clinicaltrials.gov/show/NCT00327015.

65 Boehringer Ingelheim Pharmaceuticals. Efficacy and safety of 3 doses of Bl1356 (linagliptin) in type 2 diabetes patients. National Library of Medicine (US), 2000. http:// clinicaltrials.gov/show/NCT00328172

66 Takeda. Efficacy of alogliptin with pioglitazone $($ Actos $®)$ in subjects with type 2 diabetes mellitus. National Library of Medicine (US), 2000. http://clinicaltrials.gov/show/ NCT00395512.

67 Merck. MK0431A comparative study in patients with type 2 diabetes. National Library of Medicine (US), 2000. http://clinicaltrials.gov/show/NCT00482729.

68 AstraZeneca; Bristol-Myers Squibb. 52-week add-on to metformin comparison of saxagliptin and sulphonylurea, with a 52-week extension period. National Library of Medicine (US), 2000. http://clinicaltrials.gov/show/NCT00575588.

69 AstraZeneca; Bristol-Myers Squibb. Treatment effect of saxagliptin compared with placebo in patients with type 2 diabetes and renal impairment. National Library of Medicine (US), 2000. http://clinicaltrials.gov/show/NCT00614939.

70 Merck. MK0431 and pioglitazone co-administration factorial study in patients with type 2 diabetes mellitus (0431-102 AM2). National Library of Medicine (US), 2000. http:// clinicaltrials.gov/show/NCT00722371.

71 Bristol-Myers Squibb. Safety and efficacy of saxagliptin plus insulin with or without metformin. National Library of Medicine (US), 2000. http://clinicaltrials.gov/show/ NCT00757588.

72 Boehringer Ingelheim Pharmaceuticals; Eli Lilly and Company. Efficacy and safety of linagliptin in combination with insulin in patients with type 2 diabetes. National Library of Medicine (US), 2000. http://clinicaltrials.gov/show/NCT00954447.
73 Janssen Research and Development, LLC. The CANTATA-D2 trial (CANagliflozin treatment and trial analysis-DPP-4 Inhibitor Second Comparator Trial). National Library of Medicine (US), 2000. http://clinicaltrials.gov/show/NCT01137812.

74 Boehringer Ingelheim Pharmaceuticals. Comprehensive add on study in Japan. National Library of Medicine (US), 2000. http://clinicaltrials.gov/show/NCT01204294.

75 Takeda. Efficacy and safety of alogliptin in participants with type 2 diabetes. National Library of Medicine (US), 2000. http://clinicaltrials.gov/show/NCT01289119.

76 Pan CY, Yang W, Tou C, Gause-Nilsson I, Zhao J. Efficacy and safety of saxagliptin in drug-naive Asian patients with type 2 diabetes mellitus: a randomized controlled trial. Diabetes Metab Res Rev 2012;28:268-75.

77 Pratley RE, Urosevic D, Boldrin M, Balena R. Efficacy and tolerability of taspoglutide versus pioglitazone in subjects with type 2 diabetes uncontrolled with sulphonylurea or sulphonylurea-metformin therapy: a randomized, double-blind study (T-emerge 6). Diabetes Obes Metab 2013;15:234-40.

78 Ratner RE, Rosenstock J, Boka G; DR16012 Investigators. Dose-dependent effects of the once-daily GLP-1 receptor agonist lixisenatide in patients with type 2 diabetes inadequately controlled with metformin: a randomized, double-blind, placebo-controlled trial. Diabet Med 2010;27:1024-32.

79 Raz I, Hoekstra J, Fonseca V, Boldrin M, Kipnes M, Balena R, et al. Efficacy and safety of taspoglutide monotherapy in drug-naive type 2 diabetic patients after 24 weeks of treatment: results of a randomized, double-blind, placebo-controlled phase 3 study (T-emerge 1). Diabetes Care 2012;35:485-7.

80 Rosenstock J, Reusch J, Bush M, Yang F, Stewart M. Potential of albiglutide, a long-acting GLP-1 receptor agonist, in type 2 diabetes: a randomized controlled trial exploring weekly, biweekly, and monthly dosing. Diabetes Care 2009;32:1880-6.

81 Rosenstock J, Rendell MS, Gross JL, Fleck PR, Wilson CA, Mekki Q. Alogliptin added to insulin therapy in patients with type 2 diabetes reduces $\mathrm{HbA} 1 \mathrm{c}$ without causing weight gain or increased hypoglycaemia. Diabetes Obes Metab 2009;11:1145-52.

82 Ross SA, Rafeiro E, Meinicke T, Toorawa R, Weber-Born S, Woerle HJ. Efficacy and safety of linagliptin $2.5 \mathrm{mg}$ twice daily versus $5 \mathrm{mg}$ once daily in patients with type 2 diabetes inadequately controlled on metformin: a randomised, double-blind, placebo-controlled trial. Curr Med Res Opin 2012;28:1465-74.

83 Russell-Jones D, Vaag A, Schmitz O, Sethi BK, Lalic N, Antic S, et al. Liraglutide vs insulin glargine and placebo in combination with metformin and sulfonylurea therapy in type 2 diabetes mellitus (LEAD-5 met+SU): a randomised controlled trial. Diabetologia 2009;52:2046-55.

84 Russell-Jones D, Cuddihy RM, Hanefeld M, Kumar A, Gonzalez JG, Chan M, et al. Efficacy and safety of exenatide once weekly versus metformin, pioglitazone, and sitagliptin used as monotherapy in drug-naive patients with type 2 diabetes (DURATION-4): a 26-week double-blind study. Diabetes Care 2012;35:252-8.

85 Seino Y, Rasmussen MF, Nishida T, Kaku K. Efficacy and safety of the once-daily human GLP-1 analogue, liraglutide, vs glibenclamide monotherapy in Japanese patients with type 2 diabetes. Curr Med Res Opin 2010;26:1013-22.

86 Seino Y, Miyata Y, Hiroi S, Hirayama M, Kaku K. Efficacy and safety of alogliptin added to metformin in Japanese patients with type 2 diabetes: a randomized, double-blind, placebo-controlled trial with an open-label, long-term extension study. Diabetes Obes Metab 2012;14:927-36.

87 Seino Y, Min KW, Niemoeller E, Takami A, Abe N, Arai K, et al. Randomized, double-blind, placebo-controlled trial of the once-daily GLP-1 receptor agonist lixisenatide in Asian patients with type 2 diabetes insufficiently controlled on basal insulin with or without a sulfonylurea (GetGoal-L-Asia). Diabetes Obes Metab 2012:14:910-7.

88 Umpierrez GE, Blevins T, Rosenstock J, Cheng C, Anderson JH, Bastyr EJ. The effects of LY2189265, a long-acting glucagon-like peptide-1 analogue, in a randomized, placebo-controlled, double-blind study of overweight/obese patients with type 2 diabetes: the EGO study. Diabetes Obes Metab 2011;13:418-25.

89 Yang W, Chen L, Ji Q, Liu X, Ma J, Tandon N, et al. Liraglutide provides similar glycaemic control as glimepiride (both in combination with metformin) and reduces body weight and systolic blood pressure in Asian population with type 2 diabetes from China, South Korea and India: a 16-week, randomized, double-blind, active control trial. Diabetes Obes Metab 2011;13:81-8

90 Zinman B, Gerich J, Buse JB, Lewin A, Schwartz S, Raskin P, et al. Efficacy and safety of the human glucagon-like peptide-1 analog liraglutide in combination with metformin and thiazolidinedione in patients with type 2 diabetes (LEAD-4 Met+TZD). Diabetes Care 2009;32:1224-30.

91 Garg R, Chen W, Pendergrass M. Acute pancreatitis in type 2 diabetes treated with exenatide or sitagliptin: a retrospective observational pharmacy claims analysis. Diabetes Care 2010;33:2349-54.

92 Romley JA, Goldman DP, Solomon M, McFadden D, Peters AL. Exenatide therapy and the risk of pancreatitis and pancreatic cancer in a privately insured population. Diabetes Technol Ther 2012:14:904-11.

93 Sudhakaran C, Kishore U, Anjana RM, Unnikrishnan R, Mohan V. Effectiveness of sitagliptin in asian Indian patients with type 2 diabetes-an Indian tertiary diabetes care center experience. Diabetes Technol Ther 2011;13:27-32.

94 Singh S, Chang HY, Richards TM, Weiner JP, Clark JM, Segal JB. Glucagonlike peptide 1-based therapies and risk of hospitalization for acute pancreatitis in type 2 diabetes mellitus: a population-based matched case-control study. JAMA Intern Med 2013;173:534-9.

95 Giorda CB, Picariello R, Nada E, Tartaglino B, Marafetti L, Costa G, et al. Incretin therapies and risk of hospital admission for acute pancreatitis in an unselected population of European patients with type 2 diabetes: a case-control study. Lancet Diabetes Endocrinol 2014;2:111-5.

96 Dore DD, Seeger JD, Chan KA. Use of a claims-based active drug safety surveillance system to assess the risk of acute pancreatitis with exenatide or sitagliptin compared to metformin or glyburide. Curr Med Res Opin 2009;25:1019-27.

97 Dore DD, Bloomgren GL, Wenten M, Hoffman C, Clifford CR, Quinn SG, et al. A cohort study of acute pancreatitis in relation to exenatide use. Diabetes Obes Metab 2011;13:559-66.

98 Wenten M, Gaebler JA, Hussein M, Pelletier EM, Smith DB, Girase P, et al. Relative risk of acute pancreatitis in initiators of exenatide twice daily compared with other anti-diabetic medication: a follow-up study. Diabet Med 2012;29:1412-8.

99 Halfdanarson TR, Pannala R. Incretins and risk of neoplasia. BMJ 2013;346:ł3750.

100 Alves C, Batel-Marques F, Macedo AF. A meta-analysis of serious adverse events reported with exenatide and liraglutide: acute pancreatitis and cancer. Diabetes Res Clin Pract 2012;98:271-84. 
101 Monami M, Dicembrini I, Mannucci E. Dipeptidyl peptidase-4 inhibitors and pancreatitis risk: a meta-analysis of randomized clinical trials. Diabetes Obes Metab 2014;16:48-56. 102 SAFEGUARD. SAFEGUARD safety evaluation of adverse reactions in diabetes. www. safeguard-diabetes.org/?q=content/home.

Accepted: 19 March 2014
Cite this as: BMJ 2014;348:g2366

This is an Open Access article distributed in accordance with the Creative Commons Attribution Non Commercial (CC BY-NC 3.0) license, which permits others to distribute, remix, adapt, build upon this work non-commercially, and license their derivative works on different terms, provided the original work is properly cited and the use is non-commercial. See: http://creativecommons.org/licenses/by-nc/3.0/. 


\section{Tables}

\section{Table 1 Characteristics of randomised controlled trials of incretin treatment in patients with type 2 diabetes mellitus}

\begin{tabular}{|c|c|c|c|c|c|c|c|c|c|c|c|c|c|}
\hline Author (year) & $\begin{array}{l}\text { International } \\
\text { study }\end{array}$ & $\begin{array}{l}\text { No of } \\
\text { countries } \\
\text { involved }\end{array}$ & $\begin{array}{l}\text { No of } \\
\text { study } \\
\text { sites }\end{array}$ & $\begin{array}{l}\text { Study } \\
\text { phase }\end{array}$ & $\begin{array}{c}\text { Total No } \\
\text { of } \\
\text { patients }\end{array}$ & $\begin{array}{l}\text { No of } \\
\text { groups }\end{array}$ & $\begin{array}{l}\text { Follow } \\
\text { up } \\
\text { (weeks) }\end{array}$ & No (\%) male & $\begin{array}{c}\text { Mean } \\
\text { age } \\
\text { (years) }\end{array}$ & $\begin{array}{c}\text { Mean } \\
\text { BMI }\end{array}$ & $\begin{array}{c}\text { Mean } \\
\text { HbA1c } \\
(\%)\end{array}$ & $\begin{array}{c}\text { Mean } \\
\text { FPG } \\
(\mathrm{mmol} / \mathrm{L})\end{array}$ & $\begin{array}{c}\text { Mean } \\
\text { diabetes } \\
\text { duration } \\
\text { (years) }\end{array}$ \\
\hline Araki $(2013)^{36}$ & No & 1 & 47 & III & 561 & 4 & 12 & $395(70.4)$ & 60 & 25 & 8 & 9.1 & $\begin{array}{c}286 \\
(51.0)^{*}\end{array}$ \\
\hline Barnett (2012) ${ }^{37}$ & Yes & 7 & 53 & III & 227 & 2 & 18 & $88(38.8)$ & 56.5 & 29.5 & 8.1 & 10.1 & $\begin{array}{c}165 \\
(75.0)^{*}\end{array}$ \\
\hline Bergenstal $(2010)^{38}$ & Yes & 3 & 72 & III & 514 & 3 & 26 & $254(51.7)$ & 52.3 & 32 & 8.5 & 9.1 & 5.7 \\
\hline Bunck (2009) ${ }^{39}$ & Yes & 3 & 3 & III & 69 & 2 & 52 & $45(65.2)$ & 58.4 & 30.5 & 7.5 & 9.2 & 4.9 \\
\hline Buse $(2011)^{40}$ & Yes & 5 & 59 & III & 261 & 2 & 30 & $148(57.1)$ & 59 & 33.5 & 8.4 & 8.1 & 12 \\
\hline Chacra $(2011)^{41}$ & Yes & NR & NR & III & 768 & 3 & 76 & $346(45.1)$ & 55.1 & 29 & 8.4 & 9.6 & 6.9 \\
\hline Diamant (2010) $)^{42}$ & Yes & 16 & 72 & III & 467 & 2 & 26 & $243(53.3)$ & 58 & 32 & 8.3 & 9.8 & 7.9 \\
\hline Fonseca $(2012)^{43}$ & Yes & 12 & 61 & III & 361 & 2 & 12 & $186(51.5)$ & 53.7 & 31.9 & 8 & 9 & $1.3 \neq$ \\
\hline Gallwitz (2012)a $\mathrm{a}^{44}$ & Yes & 16 & 209 & III & 1551 & 2 & 104 & $933(60.2)$ & 56.6 & 30.2 & 7.7 & 9.1 & $\begin{array}{c}715 \\
(47.1)^{*}\end{array}$ \\
\hline Gallwitz (2012)b $b^{45}$ & Yes & 14 & 128 & III & 1029 & 2 & $234 \dagger$ & $524(53.6)$ & 56 & 32.5 & 7.5 & 8.8 & 5.7 \\
\hline Garber $(2009)^{46}$ & Yes & 2 & 138 & III & 746 & 3 & 52 & $371(49.7)$ & 53 & 33.1 & 8.3 & 9.4 & 5.4 \\
\hline Grunberger (2012) & Yes & 7 & 44 & II & 164 & 5 & 12 & $74(45.1)$ & 56.6 & 32.1 & 7.3 & NR & 3.9 \\
\hline Haak $(2012)^{48}$ & Yes & 14 & 133 & III & 791 & 6 & 24 & $426(53.9)$ & 55.3 & 29.1 & 8.7 & 10.9 & $\begin{array}{c}562 \\
(74.3)^{*} \\
\end{array}$ \\
\hline Henry $(2012)^{49}$ & Yes & 8 & 113 & III & 326 & 3 & 24 & $170(54.3)$ & 54.1 & 32.6 & 8.1 & 9.4 & 7.7 \\
\hline Hollander $(2011)^{50}$ & Yes & 8 & 133 & III & 565 & 3 & 76 & $280(49.6)$ & 54 & 30 & 8.3 & 9.0 & 5.2 \\
\hline Hollander $(2012)^{51}$ & Yes & 8 & 63 & III & 305 & 2 & 24 & $119(40.8)$ & 53.5 & 36.7 & 7.5 & 8.9 & 5.1 \\
\hline Inagaki $(2012)^{52}$ & No & 1 & NR & III & 427 & 2 & 26 & $290(67.9)$ & 56.8 & 26.1 & 8.5 & NR & 9 \\
\hline Kadowaki (2009) ${ }^{53}$ & No & 1 & 20 & II & 153 & 4 & 12 & $104(68.9)$ & 60.3 & 25.3 & 8 & 9.2 & 11.9 \\
\hline Kaku $(2010)^{54}$ & No & 1 & 49 & NR & 264 & 3 & 24 & $169(64)$ & 59.7 & 24.9 & 8.4 & 9.5 & 10.3 \\
\hline Kikuchi $(2010)^{55}$ & No & 1 & 29 & III & 202 & 2 & 12 & $144(71.3)$ & 59.7 & 24.5 & 7.9 & 9.1 & 9.2 \\
\hline Kothny (2012) ${ }^{56}$ & Yes & 13 & 108 & NR & 369 & 2 & 52 & $207(56.1)$ & 66.5 & 30.3 & 7.8 & 8.8 & 16.6 \\
\hline Marre $(2009)^{57}$ & Yes & 21 & 116 & III & 1041 & 5 & 26 & $516(49.6)$ & 56.1 & 29.9 & 8.4 & 9.8 & $6.6 \neq$ \\
\hline Nauck $(2009)^{58}$ & Yes & 49 & NR & II & 306 & 6 & 12 & $143(48.1)$ & 55.7 & 32.7 & 7.9 & NR & 5.3 \\
\hline Nauck (2013) $a^{59}$ & Yes & 25 & 187 & III & 1049 & 3 & 24 & $549(53.4)$ & 57.7 & 32.4 & 8.3 & 11.1 & 9.3 \\
\hline Nauck (2013)b ${ }^{60}$ & Yes & 21 & 170 & III & 1091 & 5 & 104 & 635 (58.2) & 56.7 & 31 & 8.4 & 10 & 7.6 \\
\hline $\begin{array}{l}\text { NCT00082381 } \\
(2009)^{61}\end{array}$ & Yes & 13 & 82 & III & 551 & 2 & 26 & $306(55.7)$ & 58.9 & 31.4 & 8.2 & 10.2 & 9.6 \\
\hline $\begin{array}{l}\text { NCT00094770 } \\
(2009)^{62}\end{array}$ & Yes & NR & 173 & III & 1172 & 2 & 104 & 694 (59.2) & 56.7 & 31.2 & 7.7 & 9.2 & 6.4 \\
\hline $\begin{array}{l}\text { NCT00103857 } \\
(2009)^{63}\end{array}$ & Yes & NR & 140 & III & 915 & 5 & 104 & $539(49.4)$ & 53.5 & NR & 8.8 & 11.1 & NR \\
\hline $\begin{array}{l}\text { NCT00327015 } \\
(2009)^{64}\end{array}$ & Yes & 13 & 211 & III & 1306 & 4 & 24 & $643(49.2)$ & 52 & 30.2 & 9.5 & 11.1 & 1.7 \\
\hline $\begin{array}{l}\text { NCT00328172 } \\
(2011)^{65}\end{array}$ & Yes & 6 & 71 & II & 302 & 5 & 12 & 175 (57.9) & 57.3 & 31.1 & 8.3 & 10.5 & NR \\
\hline $\begin{array}{l}\text { NCT00395512 } \\
(2013)^{66}\end{array}$ & Yes & 23 & 268 & III & 655 & 4 & 26 & $320(48.9)$ & 52.6 & 31.1 & 8.8 & 10.6 & 3.2 \\
\hline $\begin{array}{l}\text { NCT00482729 } \\
(2009)^{67}\end{array}$ & Yes & 2 & 229 & III & 1250 & 2 & 44 & $708(56.8)$ & 49.7 & NR & 9.9 & NR & NR \\
\hline $\begin{array}{l}\begin{array}{l}\text { NCT00575588 } \\
(2010)^{68}\end{array} \\
\end{array}$ & Yes & 11 & 130 & III & 858 & 2 & 104 & $444(51.7)$ & 57.5 & 31.4 & 7.7 & 9 & 5.4 \\
\hline $\begin{array}{l}\text { NCT00614939 } \\
(2011)^{69}\end{array}$ & Yes & 14 & 75 & III & 170 & 2 & 52 & 73 (42.9) & 66.5 & 30.7 & 8.3 & 9.9 & 16.7 \\
\hline
\end{tabular}


Table 1 (continued)

\begin{tabular}{|c|c|c|c|c|c|c|c|c|c|c|c|c|c|}
\hline Author (year) & $\begin{array}{l}\text { International } \\
\text { study }\end{array}$ & $\begin{array}{c}\text { No of } \\
\text { countries } \\
\text { involved }\end{array}$ & $\begin{array}{l}\text { No of } \\
\text { study } \\
\text { sites }\end{array}$ & $\begin{array}{l}\text { Study } \\
\text { phase }\end{array}$ & $\begin{array}{c}\text { Total No } \\
\text { of } \\
\text { patients }\end{array}$ & $\begin{array}{l}\text { No of } \\
\text { groups }\end{array}$ & $\begin{array}{c}\text { Follow } \\
\text { up } \\
\text { (weeks) }\end{array}$ & No (\%) male & $\begin{array}{c}\text { Mean } \\
\text { age } \\
\text { (years) }\end{array}$ & $\begin{array}{c}\text { Mean } \\
\text { BMI }\end{array}$ & $\begin{array}{c}\text { Mean } \\
\text { HbA1c } \\
(\%)\end{array}$ & $\begin{array}{c}\text { Mean } \\
\text { FPG } \\
\text { (mmol/L) }\end{array}$ & $\begin{array}{c}\text { Mean } \\
\text { diabetes } \\
\text { duration } \\
\text { (years) }\end{array}$ \\
\hline $\begin{array}{l}\text { NCT00722371 } \\
(2011)^{70}\end{array}$ & NR & NR & NR & III & 1615 & 7 & 54 & $912(56.5)$ & NR & $N R$ & NR & NR & NR \\
\hline $\begin{array}{l}\text { NCT00757588 } \\
(2011)^{71}\end{array}$ & Yes & 10 & 72 & III & 455 & 2 & 52 & $188(41.3)$ & 57.2 & 32.3 & 8.7 & 9.6 & 11.9 \\
\hline $\begin{array}{l}\text { NCT00954447 } \\
(2012)^{72}\end{array}$ & Yes & 19 & 167 & III & 1261 & 2 & 52 & $658(52.2)$ & 60 & 31 & 8.3 & 8.3 & NR \\
\hline $\begin{array}{l}\text { NCT01137812 } \\
(2013)^{73}\end{array}$ & Yes & 17 & 140 & III & 755 & 2 & 52 & $422(55.9)$ & 56.5 & NR & NR & NR & NR \\
\hline $\begin{array}{l}\text { NCT01204294 } \\
(2012)^{74} \\
\end{array}$ & No & 1 & 43 & III & 352 & 4 & 52 & $246(69.9)$ & 61.3 & NR & 8 & NR & NR \\
\hline $\begin{array}{l}\text { NCT01289119 } \\
(2013)^{75}\end{array}$ & No & 1 & 30 & III & 506 & 6 & 16 & $275(54.3)$ & 52.6 & 25.7 & NR & NR & 4.1 \\
\hline $\operatorname{Pan}(2012)^{76}$ & Yes & 4 & 40 & III & 568 & 2 & 24 & $315(55.5)$ & 51.4 & 25.9 & 8.2 & 9.1 & 1 \\
\hline Pratley $(2013)^{77}$ & Yes & 17 & 130 & III & 760 & 3 & 24 & $362(48.9)$ & 56.4 & 32.7 & 8.3 & 10 & 8.8 \\
\hline Ratner $(2010)^{78}$ & Yes & 7 & 133 & NR & 542 & 9 & 13 & $270(49.8)$ & 56.2 & 31.9 & 7.5 & 8.8 & 6.6 \\
\hline $\operatorname{Raz}(2012)^{79}$ & Yes & NR & 53 & III & 373 & 3 & 24 & $130(36.7)$ & 54.8 & 32.3 & 7.6 & 8.8 & 2.4 \\
\hline $\begin{array}{l}\text { Rosenstock (2009) } \\
a^{80}\end{array}$ & Yes & 4 & 118 & II & 361 & 10 & 16 & $170(47.8)$ & 53.5 & 32.1 & 8 & 9.8 & 4.9 \\
\hline $\begin{array}{l}\text { Rosenstock (2009) } \\
b^{81}\end{array}$ & Yes & 13 & 110 & III & 390 & 3 & 26 & $161(41.3)$ & 55.4 & 32.5 & 9.3 & 10.6 & 12.6 \\
\hline Ross $(2012)^{82}$ & Yes & 9 & 81 & ॥ & 491 & 3 & 12 & $280(57.0)$ & 58.6 & 29.6 & 8 & 9.2 & $\begin{array}{c}227 \\
(47.5)^{\star}\end{array}$ \\
\hline $\begin{array}{l}\text { Russell-Jones } \\
(2009)^{83}\end{array}$ & Yes & 17 & 107 & III & 581 & 3 & 26 & $326(56.6)$ & 57.5 & 30.5 & 8.3 & NR & 9.4 \\
\hline $\begin{array}{l}\text { Russell-Jones } \\
(2012)^{84}\end{array}$ & Yes & 22 & 124 & III & 820 & 4 & 26 & $484(59.0)$ & 53.8 & 31.2 & 8.5 & NR & 2.7 \\
\hline Seino $(2010)^{85}$ & No & 1 & 75 & III & 411 & 2 & 24 & $268(67)$ & 58.3 & 24.5 & 8.9 & 11.3 & 8.2 \\
\hline Seino (2012) $a^{86}$ & No & 1 & 30 & III & 288 & 3 & 12 & $198(68.8)$ & 52.6 & 25.9 & 8 & NR & 6.3 \\
\hline Seino $(2012) b^{87}$ & Yes & 4 & 57 & III & 311 & 2 & 24 & $149(47.9)$ & 58.4 & 25.3 & 8.5 & 7.7 & 13.9 \\
\hline Umpierrez (2011) ${ }^{88}$ & Yes & 2 & 39 & ॥ & 262 & 2 & 16 & $129(36.4)$ & 56.5 & 33.9 & 8.2 & NR & 8.3 \\
\hline Yang $(2011)^{89}$ & Yes & 3 & 51 & NR & 929 & 4 & 16 & $514(55.3)$ & 53.3 & 25.6 & 8.6 & 9.7 & 7.5 \\
\hline Zinman (2009) ${ }^{90}$ & Yes & 2 & 96 & III & 533 & 3 & 26 & $302(56.7)$ & 55 & 33.5 & 8.5 & 10.1 & 9 \\
\hline
\end{tabular}

$\mathrm{BMI}=$ body mass index; $\mathrm{FPG}=$ fasting plasma glucose; $\mathrm{NR}=$ not reported.

*No (\%) of patients with no more than 5 years' diabetes duration.

†Longest follow-up time (weeks).

¥Median duration of diabetes (years). 


\begin{tabular}{|c|c|c|c|c|c|c|}
\hline \multirow[b]{2}{*}{ Author (year) } & \multirow[b]{2}{*}{ Drugs used across groups } & \multicolumn{2}{|c|}{ Incretin } & \multicolumn{2}{|l|}{ Control } & \multirow{2}{*}{$\begin{array}{l}\text { Follow-up from start } \\
\text { of treatment } \\
\text { (weeks) }\end{array}$} \\
\hline & & Type & Events & Type & Events & \\
\hline \multirow[t]{2}{*}{ Araki $(2013)^{36}$} & None & Linagliptin & $0 / 319$ & Placebo & $0 / 80$ & 12 \\
\hline & & Linagliptin & $0 / 319$ & Voglibose & $0 / 162$ & \\
\hline Barnett $(2012)^{37}$ & None & Linagliptin & $0 / 151$ & Placebo & $0 / 76$ & 18 \\
\hline \multirow[t]{2}{*}{ Bergenstal $(2010)^{38}$} & Metformin & Exenatide & $0 / 160$ & Pioglitazone & 2/165 & 26 \\
\hline & & Sitagliptin & $0 / 166$ & Pioglitazone & 2/165 & \\
\hline Bunck $(2009)^{39}$ & Metformin & Exenatide & $1 / 36$ & Insulin glargine & $0 / 33$ & 52 \\
\hline Buse $(2011)^{40}$ & $\begin{array}{l}\text { Insulin glargine } \pm \text { metformin/pioglitazone (or } \\
\text { both agents) }\end{array}$ & Exenatide & $0 / 137$ & Placebo & $0 / 122$ & 30 \\
\hline Chacra $(2011)^{41}$ & Glyburide & Saxagliptin & 0/501 & Placebo & 0/267 & 76 \\
\hline Diamant $(2010)^{42}$ & Metformin $\pm S U$ & Exenatide & $1 / 233$ & Insulin glargine & $0 / 223$ & 26 \\
\hline Fonseca $(2012)^{43}$ & None & Lixisenatide & $0 / 239$ & Placebo & $0 / 122$ & 12 \\
\hline Gallwitz (2012) $\mathrm{a}^{44}$ & Metformin & Linagliptin & $1 / 776$ & Glimepiride & $0 / 775$ & 104 \\
\hline Gallwitz (2012)b ${ }^{45}$ & Metformin & Exenatide & $1 / 511$ & Glimepiride & $1 / 508$ & $107^{*}$ \\
\hline Garber $(2009)^{46}$ & None & Liraglutide & $2 / 497$ & Glimepiride & $0 / 248$ & 52 \\
\hline Grunberger $(2012)^{47}$ & None & Dulaglutide & $0 / 132$ & Placebo & $1 / 32$ & 12 \\
\hline Haak $(2012)^{48}$ & None & Linagliptin & $0 / 428$ & Placebo & 0/72 & 24 \\
\hline Henry $(2012)^{49}$ & Metformin & Taspoglutide & 0/223 & Placebo & $0 / 101$ & 24 \\
\hline Hollander $(2011)^{50}$ & TZD & Saxagliptin & $1 / 381$ & Placebo & $0 / 184$ & 76 \\
\hline Hollander $(2012)^{51}$ & Metformin & Taspoglutide & $0 / 154$ & Placebo & $0 / 150$ & 24 \\
\hline Inagaki (2012) ${ }^{52}$ & $B G$ or $B G+T Z D$ & Exenatide & $0 / 215$ & Insulin glargine & $0 / 212$ & 26 \\
\hline Kadowaki $(2009)^{53}$ & $\mathrm{SU} \pm \mathrm{BG} / \mathrm{TZD}$ & Exenatide & $0 / 111$ & Placebo & $0 / 40$ & 12 \\
\hline Kaku $(2010)^{54}$ & SU (glibenclamide, glicazide or glimeprimide) & liraglutide & $0 / 176$ & Placebo & $0 / 88$ & 24 \\
\hline Kikuchi $(2010)^{55}$ & Glimepiride & Vildagliptin & $0 / 102$ & Placebo & $0 / 100$ & 12 \\
\hline Kothny $(2012)^{56}$ & Untreated, insulin, OADs or any combination & Vildagliptin & $0 / 216$ & Placebo & $0 / 153$ & 52 \\
\hline \multirow[t]{2}{*}{ Marre $(2009)^{57}$} & Glimepiride & Liraglutide & $1 / 695$ & Placebo & $0 / 114$ & 26 \\
\hline & & Liraglutide & $1 / 695$ & Rosiglitazone & $0 / 231$ & \\
\hline Nauck (2009) $)^{58}$ & Metformin & Taspoglutide & $0 / 248$ & Placebo & $0 / 49$ & 12 \\
\hline Nauck (2013)a $a^{59}$ & Metformin & Taspoglutide & $0 / 715$ & Insulin glargine & $0 / 322$ & 24 \\
\hline \multirow[t]{2}{*}{ Nauck (2013) $b^{60}$} & Metformin & Liraglutide & $1 / 724$ & Placebo & $0 / 121$ & 104 \\
\hline & & Liraglutide & $1 / 724$ & Glimepiride & $1 / 242$ & \\
\hline NCT00082381 (2009) $)^{61}$ & Metformin + SU & Exenatide & $0 / 282$ & Insulin glargine & $1 / 267$ & 26 \\
\hline NCT00094770 (2009) ${ }^{62}$ & Metformin & Sitagliptin & $1 / 588$ & Glipizide & $0 / 584$ & 104 \\
\hline NCT00103857 (2009) ${ }^{63}$ & None & Sitagliptin & $1 / 551$ & Metformin & $0 / 364$ & 104 \\
\hline NCT00327015 (2009) $)^{64}$ & None & Saxagliptin & $0 / 978$ & Metformin & $1 / 328$ & 24 \\
\hline \multirow[t]{2}{*}{ NCT00328172 (2011) ${ }^{65}$} & None & Linagliptin & $1 / 170$ & Placebo & $0 / 67$ & 12 \\
\hline & & Linagliptin & $1 / 170$ & Metformin & $0 / 65$ & \\
\hline NCT00395512 (2013) 66 & None & Alogliptin & $1 / 491$ & Pioglitazone & $0 / 163$ & 26 \\
\hline NCT00482729 (2009) & Metformin & Sitagliptin & $1 / 625$ & No additional drug & $0 / 621$ & 44 \\
\hline NCT00575588 (2010) ${ }^{68}$ & Metformin & Saxagliptin & $0 / 428$ & Glipizide & $1 / 430$ & 104 \\
\hline NCT00614939 (2011) 69 & OADs and/or insulin & Saxagliptin & $0 / 85$ & Placebo & $1 / 85$ & 52 \\
\hline NCT00722371 (2011) 70 & None & Sitagliptin & $0 / 922$ & Pioglitazone & $1 / 693$ & 54 \\
\hline NCT00757588 (2011) & Insulin \pm metformin & Saxagliptin & $0 / 304$ & Placebo & $0 / 151$ & 52 \\
\hline NCT00954447 (2012) ${ }^{72}$ & Insulin and/or metformin and/or pioglitazone & Linagliptin & $3+/ 631$ & Placebo & $1 / 630$ & 52 \\
\hline NCT01137812 (2013) ${ }^{73}$ & Metformin + SU & Sitagliptin & $0 / 378$ & Canagliflozin & $1 / 377$ & 52 \\
\hline NCT01204294 (2012) & SU or A-GI & Linagliptin & $0 / 228$ & Metformin & $0 / 124$ & 52 \\
\hline \multirow[t]{2}{*}{ NCT01289119 (2013) ${ }^{75}$} & None & Alogliptin & $0 / 252$ & Placebo & $1 / 92$ & 16 \\
\hline & & Alogliptin & $0 / 252$ & Metformin & $0 / 98$ & \\
\hline
\end{tabular}


Table 2 (continued)

\begin{tabular}{|c|c|c|c|c|c|c|}
\hline \multirow[b]{2}{*}{ Author (year) } & \multirow[b]{2}{*}{ Drugs used across groups } & \multicolumn{2}{|c|}{ Incretin } & \multicolumn{2}{|c|}{ Control } & \multirow{2}{*}{$\begin{array}{l}\text { Follow-up from start } \\
\text { of treatment } \\
\text { (weeks) }\end{array}$} \\
\hline & & Type & Events & Type & Events & \\
\hline & & Alogliptin & $0 / 252$ & Pioglitazone & $0 / 63$ & \\
\hline Pan $(2012)^{76}$ & None & Saxagliptin & $0 / 284$ & Placebo & $0 / 284$ & 24 \\
\hline Pratley $(2013)^{77}$ & $\mathrm{SU} \pm$ metformin & Taspoglutide & $1 / 494$ & Pioglitazone & $0 / 257$ & 24 \\
\hline Ratner $(2010)^{78}$ & Metformin & Lixisenatide & $0 / 433$ & Placebo & $0 / 109$ & 13 \\
\hline $\operatorname{Raz}(2012)^{79}$ & None & Taspoglutide & $0 / 245$ & Placebo & $0 / 123$ & 24 \\
\hline \multirow[t]{2}{*}{ Rosenstock (2009) $a^{80}$} & None & Exenatide & $0 / 35$ & Placebo & $0 / 51$ & 16 \\
\hline & & Albiglutide & $0 / 270$ & Placebo & $0 / 51$ & \\
\hline Rosenstock (2009)b ${ }^{81}$ & Insulin \pm metformin & Alogliptin & $2 / 260$ & Placebo & $0 / 129$ & 26 \\
\hline Ross $(2012)^{82}$ & metformin & Linagliptin & $0 / 447$ & Placebo & $0 / 44$ & 12 \\
\hline \multirow[t]{2}{*}{ Russell-Jones (2009) ${ }^{83}$} & Metformin + glimepiride & Liraglutide & $0 / 230$ & Placebo & $0 / 114$ & \\
\hline & & Liraglutide & $0 / 230$ & Insulin glargine & $0 / 232$ & 26 \\
\hline \multirow[t]{4}{*}{ Russell-Jones (2012) ${ }^{84}$} & None & Exenatide & $0 / 248$ & Metformin & $0 / 246$ & 26 \\
\hline & & Exenatide & $0 / 248$ & Pioglitazone & $0 / 163$ & \\
\hline & & Sitagliptin & $1 / 163$ & Metformin & $0 / 246$ & \\
\hline & & Sitagliptin & $1 / 163$ & Pioglitazone & $0 / 163$ & \\
\hline Seino $(2010)^{85}$ & None & Liraglutide & $0 / 268$ & Glibenclamide & $0 / 132$ & 24 \\
\hline Seino (2012) $a^{86}$ & Metformin & Alogliptin & $0 / 188$ & Placebo & $0 / 100$ & 12 \\
\hline Seino $(2012) b^{87}$ & Insulin \pm SU & Lixisenatide & $0 / 154$ & Placebo & $0 / 157$ & 24 \\
\hline Umpierrez $(2011)^{88}$ & $\begin{array}{l}\text { Each of the two different classes (SU, } \\
\text { biguanide, TZD or DPP-4) }\end{array}$ & Dulaglutide & $2 / 196$ & Placebo & $0 / 66$ & 16 \\
\hline Yang $(2011)^{89}$ & Metformin & Liraglutide & $0 / 697$ & Glimepiride & $0 / 231$ & 16 \\
\hline Zinman $(2009)^{90}$ & Metformin + rosiglitazone & Liraglutide & $0 / 356$ & Placebo & $0 / 177$ & 26 \\
\hline
\end{tabular}

$\mathrm{SU}=$ sulfonylurea; $\mathrm{TZD}=$ thiazolidinedione; $\mathrm{BG}=$ biguanide; $\mathrm{OADs}=$ oral antidiabetic drugs.

*Average treatment time (weeks); A-GI, alpha-glucosidase inhibitor.

†Pancreatitis events data extracted from additional information reported in ClinicalTrials.gov. 


\begin{tabular}{|c|c|c|c|c|c|c|c|c|c|c|c|}
\hline $\begin{array}{l}\text { Author } \\
\text { (year) }\end{array}$ & Study design & $\begin{array}{c}\text { Data } \\
\text { source/country }\end{array}$ & Funding & Inclusion criteria & Exclusion criteria & $\begin{array}{l}\text { No }(\%) \\
\text { male }\end{array}$ & $\begin{array}{l}\text { Mean } \\
\text { age } \\
\text { (years) }\end{array}$ & $\begin{array}{c}\text { Mean } \\
\text { BMI }\end{array}$ & $\begin{array}{c}\text { Mean } \\
\text { HbA1c } \\
(\%)\end{array}$ & $\begin{array}{c}\text { Mean } \\
\text { FPG } \\
(\mathrm{mmol} / \mathrm{L})\end{array}$ & $\begin{array}{c}\text { Mean } \\
\text { diabetes } \\
\text { duration } \\
\text { (years) }\end{array}$ \\
\hline $\begin{array}{l}\text { Garg } \\
(2010)^{91}\end{array}$ & $\begin{array}{l}\text { Retrospective } \\
\text { cohort study }\end{array}$ & Claims data/US & NR & $\begin{array}{l}\text { Diabetic patients aged } \\
18-63 \text { years with pharmacy } \\
\text { and medical claims data } \\
\text { for continuous period of at } \\
\text { least } 12 \text { months between } \\
1 \text { January } 2007 \text { and } 30 \\
\text { June } 2009\end{array}$ & $\begin{array}{l}\text { Patients aged }>63 \\
\text { because of } \\
\text { possibility of } \\
\text { incomplete medical } \\
\text { data; patients with } \\
\text { acute pancreatitis } 6 \\
\text { months before or on } \\
\text { index date; treatment } \\
\text { with repaglinide, } \\
\text { nateglinide, } \\
\text { acarbose, or miglitol } \\
\text { and treatment with } \\
\text { both exenatide and } \\
\text { sitagliptin }\end{array}$ & $\begin{array}{l}26953 \\
(54.3)\end{array}$ & 52.7 & NR & NR & NR & NR \\
\hline $\begin{array}{l}\text { Romley } \\
(2012)^{92}\end{array}$ & $\begin{array}{l}\text { Retrospective } \\
\text { cohort study }\end{array}$ & Claims data/US & $\begin{array}{l}\text { Public } \\
\text { funding }\end{array}$ & $\begin{array}{l}\text { Patients having two or } \\
\text { more medical claims with } \\
\text { ICD-9 code of } 250 . x x \\
\text { within calendar year and } \\
\text { fewer than two claims with } \\
\text { ICD-9 code of } 250 . x 1 \\
\text { within each year, using } \\
\text { oral antidiabetes drugs at } \\
\text { any point during study } \\
\text { period, and enrolled for at } \\
\text { least } 1 \text { year during } \\
2007-09 \text { with continuously } \\
\text { enrolled throughout each } \\
\text { year, with no gaps } \\
\text { between years }\end{array}$ & $\begin{array}{l}\text { Users of sitagliptin } \\
\text { were patients aged } \\
<18 \text {; patients with } \\
\text { pancreatic cancer } \\
\text { subsequent to } \\
\text { incident cancer } \\
\text { diagnosis; patients } \\
\text { with occurrence of } \\
\text { first event before } \\
2007 \text { or before first } \\
\text { use of exenatide }\end{array}$ & $\begin{array}{l}145560 \\
(54.2)\end{array}$ & 63.1 & NR & NR & NR & 3.1 \\
\hline $\begin{array}{l}\text { Sudhakaran } \\
(2011)^{93}\end{array}$ & $\begin{array}{l}\text { Retrospective } \\
\text { cohort study }\end{array}$ & $\begin{array}{l}\text { Case } \\
\text { records/India }\end{array}$ & $\begin{array}{l}\text { No } \\
\text { financial } \\
\text { support }\end{array}$ & $\begin{array}{l}\text { Asian Indian patients with } \\
\text { type } 2 \text { diabetes in Indian } \\
\text { tertiary diabetes care } \\
\text { centre }\end{array}$ & NR & $\begin{array}{l}3512 \\
(63.2)\end{array}$ & 55.1 & 30.0 & 9.2 & 10.0 & 15.1 \\
\hline $\begin{array}{l}\text { Singh } \\
(2013)^{94}\end{array}$ & $\begin{array}{l}\text { Case-control } \\
\text { study }\end{array}$ & Claims data/US & $\begin{array}{l}\text { Public } \\
\text { funding }\end{array}$ & $\begin{array}{l}\text { Type } 2 \text { diabetes mellitus } \\
\text { patients who filled at least } \\
1 \text { prescription for any drug } \\
\text { used to treat type } 2 \\
\text { diabetes from } 1 \text { February } \\
2005 \text { to } 31 \text { December } \\
2008 \text {; patients aged 18-64 } \\
\text { on date of first code for } \\
\text { diabetes, and contributed } \\
\text { at least } 6 \text { months of } \\
\text { medical or pharmacy } \\
\text { coverage in calendar year } \\
\text { with diabetes code, and of } \\
\text { known sex }\end{array}$ & $\begin{array}{l}\text { Participants aged } \\
>64 \text { because of } \\
\text { incomplete } \\
\text { healthcare } \\
\text { information; } \\
\text { pancreatitis } \\
\text { occurrences within } 3 \\
\text { months of enrollment }\end{array}$ & $\begin{array}{r}1458 \\
(57.5)\end{array}$ & 52 & NR & NR & NR & NR \\
\hline $\begin{array}{l}\text { Giorda } \\
(2013)^{95}\end{array}$ & $\begin{array}{l}\text { Case-control } \\
\text { study }\end{array}$ & Claims data/Italy & $\begin{array}{l}\text { Non-profit } \\
\text { funding }\end{array}$ & $\begin{array}{l}\text { Type } 2 \text { diabetes patients } \\
\text { aged } \geq 41 \text { who were } \\
\text { dispensed at least one } \\
\text { dose of any drug to treat } \\
\text { diabetes between } 1 \text { Jan } \\
2008 \text { and } 31 \text { Dec } 2012\end{array}$ & $\begin{array}{l}\text { Individuals who had } \\
\text { ICD-9-CM code for } \\
\text { type } 1 \text { diabetes } \\
\text { mellitus ( } 250 . \times 1 \text { or } \\
250 . \times 3)\end{array}$ & $\begin{array}{l}2750 \\
(54.8)\end{array}$ & 72.2 & NR & NR & NR & NR \\
\hline
\end{tabular}

$\mathrm{NR}=$ not reported. 
Table 4 | Exposures, outcomes, and results of observational studies of incretin treatment and pancreatitis in patients with type 2 diabetes mellitus

\begin{tabular}{|c|c|c|c|c|c|c|}
\hline Author (year) & Exposure of interest & Control group & Outcome measures & $\begin{array}{l}\text { No of } \\
\text { events }\end{array}$ & $\begin{array}{l}\text { Total No of } \\
\text { patients }\end{array}$ & Adjusted estimates $(95 \% \mathrm{Cl})$ \\
\hline Garg $(2010)^{91}$ & Exenatide, sitagliptin & $\begin{array}{l}\text { Diabetic control group } \\
\text { (new sulfonylurea, } \\
\text { biguanide, or } \\
\text { thiazolidinedione and no } \\
\text { sitagliptin or exenatide } \\
\text { prescription) }\end{array}$ & Acute pancreatitis & 154 & 38615 & $\begin{array}{l}\text { Exenatide } v \text { control: HR } 0.9(0.6 \text { to } 1.5) \text {; } \\
\text { sitagliptin } v \text { control: HR } 1.0 \text { ( } 0.7 \text { to } 1.3)\end{array}$ \\
\hline Romley (2012) ${ }^{92}$ & Exenatide & Non-exenatide & $\begin{array}{l}\text { Admission for acute } \\
\text { pancreatitis }\end{array}$ & 1312 & 268561 & $\begin{array}{l}\text { Exenatide } v \text { control: OR } 0.93 \text { ( } 0.63 \text { to } \\
1.36)\end{array}$ \\
\hline $\begin{array}{l}\text { Sudhakaran } \\
(2011)^{93}\end{array}$ & Sitagliptin & Insulin glargine & Acute pancreatitis & 0 & 5560 & No events reported \\
\hline Singh $(2013)^{94}$ & Exenatide, sitagliptin & $\begin{array}{l}\text { No sitagliptin or exenatide } \\
\text { prescription }\end{array}$ & $\begin{array}{l}\text { Admission for acute } \\
\text { pancreatitis }\end{array}$ & 1269 & 2538 & $\begin{array}{l}\text { Current use of sitagliptin or exenatide } \\
\text { within } 30 \text { days before pancreatitis } v \text { no } \\
\text { use: OR } 2.24 \text { ( } 1.36 \text { to } 3.68 \text { ); recent use } \\
\text { past } 30 \text { days and }<2 \text { years } v \text { no use: } \\
\text { OR } 2.01 \text { ( } 1.37 \text { to } 3.18 \text { ); any use within } \\
2 \text { years } v \text { no use: OR } 2.07 \text { (1.36 to } \\
3.13 \text { ) }\end{array}$ \\
\hline Giorda $(2013)^{95}$ & $\begin{array}{l}\text { Exenatide, liraglutide, } \\
\text { sitagliptin, saxagliptin, } \\
\text { vildagliptin }\end{array}$ & Not clearly reported & $\begin{array}{l}\text { Admission for acute } \\
\text { pancreatitis }\end{array}$ & 1003 & 5015 & $\begin{array}{l}\text { All incretin agents } v \text { control: OR } 0.98 \\
(0.69 \text { to } 1.38)\end{array}$ \\
\hline
\end{tabular}

$\mathrm{HR}=$ hazard ratio; OR=odds ratio. 


\begin{tabular}{|c|c|c|c|c|c|c|c|c|}
\hline $\begin{array}{l}\text { Author } \\
\text { (year) }\end{array}$ & $\begin{array}{l}\text { Ascertainment of } \\
\text { type } 2 \text { diabetes } \\
\text { conditions }\end{array}$ & $\begin{array}{l}\text { Ascertainment } \\
\text { of exposure to } \\
\text { incretin agents }\end{array}$ & $\begin{array}{l}\text { Selection of } \\
\text { non exposed } \\
\text { cohort }\end{array}$ & $\begin{array}{l}\text { Ascertainment } \\
\text { of other } \\
\text { confounding } \\
\text { variables }\end{array}$ & $\begin{array}{l}\text { Demonstration } \\
\text { that outcome of } \\
\text { interest not } \\
\text { present at start } \\
\text { of study }\end{array}$ & $\begin{array}{l}\text { Comparability of study } \\
\text { controls for important } \\
\text { factors }\end{array}$ & $\begin{array}{l}\text { Assessment } \\
\text { of outcome }\end{array}$ & $\begin{array}{c}\text { Completeness } \\
\text { of outcome and } \\
\text { exposure } \\
\text { variables }\end{array}$ \\
\hline $\begin{array}{l}\text { Garg (2010) } \\
91\end{array}$ & $\begin{array}{l}\text { Patients with } \\
\text { diabetes identified by } \\
\text { presence of at least } \\
1 \text { ICD- } 9 \text { code of } \\
250 . X X \text { and claim for } \\
\text { new antidiabetes } \\
\text { drugs }\end{array}$ & $\begin{array}{l}\text { Statement not } \\
\text { explicit; likely } \\
\text { from new } \\
\text { antidiabetes } \\
\text { drug of } \\
\text { pharmacy } \\
\text { claims }\end{array}$ & $\begin{array}{l}\text { Drawn from } \\
\text { same } \\
\text { population as } \\
\text { exposed } \\
\text { cohort }\end{array}$ & $\begin{array}{l}\text { Risk factors for } \\
\text { acute } \\
\text { pancreatitis } \\
\text { determined from } \\
\text { ICD-9 claims } \\
\text { data }\end{array}$ & $\begin{array}{l}\text { Yes, patients with } \\
\text { acute pancreatitis } \\
6 \text { months before } \\
\text { or on index date } \\
\text { were excluded }\end{array}$ & $\begin{array}{l}\text { Cox proportional hazard } \\
\text { model built to control for } \\
\text { age, sex, } \\
\text { hypertriglyceridaemia, } \\
\text { alcohol abuse, biliary } \\
\text { stone disease, } \\
\text { cholestatic liver disease, } \\
\text { and drug therapy }\end{array}$ & $\begin{array}{l}\text { Acute } \\
\text { pancreatitis } \\
\text { determined } \\
\text { by claim for } \\
\text { ICD-9 code } \\
577.0\end{array}$ & $\begin{array}{l}\text { Completeness of } \\
\text { outcome and } \\
\text { exposure } \\
\text { variable data in } \\
\text { database not } \\
\text { mentioned }\end{array}$ \\
\hline $\begin{array}{l}\text { Romley } \\
(2012)^{92}\end{array}$ & $\begin{array}{l}\text { Patients with type } 2 \\
\text { diabetes identified } \\
\text { with ICD code } \\
(250 . X X \text { and } 250 . X 1) \\
\text { and with use of } \\
\text { antidiabetes drugs } \\
\text { identified by National } \\
\text { Drug Code within } \\
\text { pharmacy claims }\end{array}$ & $\begin{array}{l}\text { Exenatide use } \\
\text { identified by } \\
\text { National Drug } \\
\text { Code within } \\
\text { pharmacy } \\
\text { claims }\end{array}$ & $\begin{array}{l}\text { Drawn from } \\
\text { same } \\
\text { population as } \\
\text { exposed } \\
\text { cohort }\end{array}$ & $\begin{array}{l}\text { Co-morbid } \\
\text { conditions and } \\
\text { traditional } \\
\text { pancreatitis risk } \\
\text { factors, such as } \\
\text { history of } \\
\text { gallstones or } \\
\text { alcohol abuse, } \\
\text { identified from } \\
\text { ICD-9 codes }\end{array}$ & $\begin{array}{l}\text { Yes, patients } \\
\text { excluded if } \\
\text { pancreatitis } \\
\text { occurred before } \\
\text { enrolment and } \\
\text { use of exenatide }\end{array}$ & $\begin{array}{l}\text { Logistic analyses used } \\
\text { to control for influence of } \\
\text { age, sex, years since } \\
\text { diabetes diagnosis, } 19 \\
\text { co-morbid conditions, } \\
\text { and traditional risk } \\
\text { factors for pancreatitis } \\
\text { (such as gallstones or } \\
\text { alcohol abuse) }\end{array}$ & $\begin{array}{l}\text { Admission for } \\
\text { pancreatitis } \\
\text { identified by } \\
\text { inpatient } \\
\text { claims with } \\
\text { ICD-9 code } \\
577.0\end{array}$ & $\begin{array}{l}\text { Completeness of } \\
\text { outcome and } \\
\text { exposure } \\
\text { variable data in } \\
\text { database not } \\
\text { mentioned }\end{array}$ \\
\hline $\begin{array}{l}\text { Sudhakaran } \\
(2011)^{93}\end{array}$ & $\begin{array}{l}\text { Patients with type } 2 \\
\text { diabetes prescribed } \\
\text { sitagliptin or insulin } \\
\text { glargine identified } \\
\text { from medical records }\end{array}$ & $\begin{array}{l}\text { Statement not } \\
\text { explicit; likely } \\
\text { from medical } \\
\text { records }\end{array}$ & $\begin{array}{l}\text { Drawn from } \\
\text { same } \\
\text { population as } \\
\text { exposed } \\
\text { cohort }\end{array}$ & Not reported & Not reported & $\begin{array}{l}\text { No, patients had } \\
\text { significant difference in } \\
\text { age, sex, BMI, duration } \\
\text { of diabetes between } \\
\text { sitagliptin and insulin } \\
\text { glargine, and no } \\
\text { adjusted analysis } \\
\text { conducted }\end{array}$ & $\begin{array}{l}\text { Medical } \\
\text { records }\end{array}$ & $\begin{array}{l}\text { All patients with } \\
\text { complete follow } \\
\text { up }\end{array}$ \\
\hline
\end{tabular}




\begin{tabular}{|c|c|c|c|c|c|c|c|c|c|}
\hline $\begin{array}{l}\text { Author } \\
\text { (year) }\end{array}$ & $\begin{array}{l}\text { Ascertainment } \\
\text { of type } 2 \\
\text { diabetes } \\
\text { conditions }\end{array}$ & $\begin{array}{l}\text { Is case } \\
\text { definition } \\
\text { adequate }\end{array}$ & $\begin{array}{l}\text { Selection of } \\
\text { controls }\end{array}$ & $\begin{array}{l}\text { Definition } \\
\text { of controls }\end{array}$ & $\begin{array}{l}\text { Ascertainment } \\
\text { of exposure to } \\
\text { incretin agents }\end{array}$ & $\begin{array}{l}\text { Ascertainment of } \\
\text { other confounding } \\
\text { variables }\end{array}$ & $\begin{array}{l}\text { Same method } \\
\text { of } \\
\text { ascertainment } \\
\text { for exposure to } \\
\text { incretin agents }\end{array}$ & $\begin{array}{l}\text { Comparability } \\
\text { of study } \\
\text { controls for } \\
\text { important } \\
\text { factors }\end{array}$ & $\begin{array}{c}\text { Completeness } \\
\text { of data within } \\
\text { database }\end{array}$ \\
\hline $\begin{array}{l}\text { Singh } \\
(2013)^{94}\end{array}$ & $\begin{array}{l}\text { Type } 2 \text { diabetes } \\
\text { mellitus } \\
\text { identified as } 1 \\
\text { relevant } \\
\text { inpatient code } \\
\text { of ICD- } 9 \text { or } 2 \\
\text { outpatient ICD-9 } \\
\text { codes } \\
\text { separated by at } \\
\text { least } 30 \text { days } \\
(250 . x x, 648.0 \text {, } \\
362.0 \text {, and } \\
266.41)\end{array}$ & $\begin{array}{l}\text { Yes, } \\
\text { presumptive } \\
\text { cases } \\
\text { identified } \\
\text { with } \\
\text { validated } \\
\text { algorithm of } \\
\text { ICD-9 and } \\
\text { Current } \\
\text { Procedural } \\
\text { Terminology } \\
\text { codes for } \\
\text { acute } \\
\text { pancreatitis }\end{array}$ & $\begin{array}{l}\text { Each case } \\
\text { randomly } \\
\text { selected } 1 \\
\text { control subject } \\
\text { from } \\
\text { same } \\
\text { population } \\
\text { matched on } \\
\text { age within } 10 \\
\text { years, sex, } \\
\text { insurance plan } \\
\text { site, diabetes } \\
\text { complication } \\
\text { severity index } \\
\text { (0, } 1,2,3, \text { or } \\
\text { more), and } \\
\text { enrolment } \\
\text { pattern or } \\
\text { duration of } \\
\text { follow-up }\end{array}$ & $\begin{array}{l}\text { Patients } \\
\text { with no } \\
\text { acute } \\
\text { pancreatitis }\end{array}$ & $\begin{array}{l}\text { Drug exposure } \\
\text { defined as } \\
\text { having filled } \\
\text { prescription for } \\
\text { sitagliptin or } \\
\text { exenatide } \\
\text { before first } \\
\text { observed } \\
\text { diagnosis of } \\
\text { pancreatitis, and } \\
\text { prescription data } \\
\text { used as } \\
\text { indicator of drug } \\
\text { exposure }\end{array}$ & $\begin{array}{l}\text { Ascertainment of risk } \\
\text { factors for acute } \\
\text { pancreatitis not } \\
\text { mentioned }\end{array}$ & $\begin{array}{l}\text { Yes, both } \\
\text { groups used } \\
\text { drug use } \\
\text { information from } \\
\text { computerised } \\
\text { pharmacy } \\
\text { database } \\
\text { containing date } \\
\text { of prescription } \\
\text { filled and } \\
\text { supplied to } \\
\text { determine } \\
\text { exposure to } \\
\text { sitagliptin or } \\
\text { exenatide, and } \\
\text { patient with } \\
\text { exposure after } \\
\text { index diagnosis } \\
\text { of acute } \\
\text { pancreatitis } \\
\text { counted as } \\
\text { unexposed }\end{array}$ & $\begin{array}{l}\text { Logistic } \\
\text { regression } \\
\text { model used } \\
\text { control for } \\
\text { matching } \\
\text { variables, } \\
\text { potential } \\
\text { confounders } \\
\text { specified a priori } \\
\text { and identifiable } \\
\text { in claims data, } \\
\text { and metformin } \\
\text { exposure during } \\
\text { same period }\end{array}$ & $\begin{array}{l}\text { Both groups } \\
\text { had same rate } \\
\text { of missing } \\
\text { information on } \\
\text { sex }\end{array}$ \\
\hline $\begin{array}{l}\text { Giorda } \\
(2013)^{95}\end{array}$ & $\begin{array}{l}\text { Patients with } \\
\text { type } 2 \text { diabetes } \\
\text { identified as at } \\
\text { least } 1 \text { dose of } \\
\text { any drug to treat } \\
\text { diabetes and } \\
\text { patients with } \\
\text { type } 1 \text { diabetes } \\
\text { excluded by } \\
\text { ICD-9 code ( } \\
250 . \times 1 \text { or } \\
250 . \times 3 \text { ) }\end{array}$ & $\begin{array}{l}\text { Yes, cases } \\
\text { identified by } \\
\text { having at } \\
\text { least one } \\
\text { discharge for } \\
\text { acute } \\
\text { pancreatitis } \\
\text { (ICD-9 code } \\
577.0 \\
\text { discharge } \\
\text { diagnosis at } \\
\text { any time } \\
\text { after first } \\
\text { exposure to } \\
\text { antidiabetic } \\
\text { drugs) }\end{array}$ & $\begin{array}{l}\text { Each case } \\
\text { randomly } \\
\text { selected four } \\
\text { controls from } \\
\text { same } \\
\text { population } \\
\text { source, } \\
\text { matched for } \\
\text { year of birth, } \\
\text { sex, and year } \\
\text { of first } \\
\text { exposure to } \\
\text { antidiabetic } \\
\text { drugs }\end{array}$ & $\begin{array}{l}\text { Patients } \\
\text { with no } \\
\text { acute } \\
\text { pancreatitis }\end{array}$ & $\begin{array}{l}\text { Incretins } \\
\text { selected by } \\
\text { anatomical } \\
\text { therapeutic } \\
\text { chemical (ATC) } \\
\text { classification } \\
\text { system (ATC } \\
\text { codes A10BH01 } \\
\text { and A10BD07 } \\
\text { (sitagliptin), } \\
\text { A10BH02 and } \\
\text { A10BD08 } \\
\text { (vildagliptin), } \\
\text { A10BH03 } \\
\text { (saxagliptin), } \\
\text { A10BX04 } \\
\text { (exenatide), and } \\
\text { A10BX07 } \\
\text { (liraglutide)) }\end{array}$ & $\begin{array}{l}\text { Potential confounders } \\
\text { identified from ICD-9 } \\
\text { codes, such as chronic } \\
\text { or acute pancreatitis } \\
\text { (excluding episode of } \\
\text { index case (ICD-9 } \\
\text { code } 577.0 \text { )), } \\
\text { gallstones, alcohol } \\
\text { misuse, } \\
\text { hypertriglyceridaemia, } \\
\text { obesity, biliary tract or } \\
\text { pancreatic cancers, } \\
\text { cardio vascular } \\
\text { diseases, and diabetic } \\
\text { retinopathy }\end{array}$ & $\begin{array}{l}\text { Yes, both cases } \\
\text { and controls } \\
\text { who had been } \\
\text { prescribed } \\
\text { incretins } \\
\text { identified with } \\
\text { regional drug } \\
\text { database }\end{array}$ & $\begin{array}{l}\text { Logistic } \\
\text { regression } \\
\text { model built to } \\
\text { control for } \\
\text { confounders, } \\
\text { including past } \\
\text { history of } \\
\text { pancreatitis, } \\
\text { gallstones, } \\
\text { alcohol use, } \\
\text { hypertrigly } \\
\text { ceridaemia, } \\
\text { obesity, biliary } \\
\text { tract or } \\
\text { pancreatic } \\
\text { cancer, } \\
\text { cardiovascular } \\
\text { disease, and } \\
\text { metformin or } \\
\text { glibenclamide } \\
\text { use }\end{array}$ & $\begin{array}{l}\text { Authors did not } \\
\text { mention } \\
\text { completeness } \\
\text { of outcome and } \\
\text { exposure } \\
\text { variable data in } \\
\text { database }\end{array}$ \\
\hline
\end{tabular}




\section{Figures}

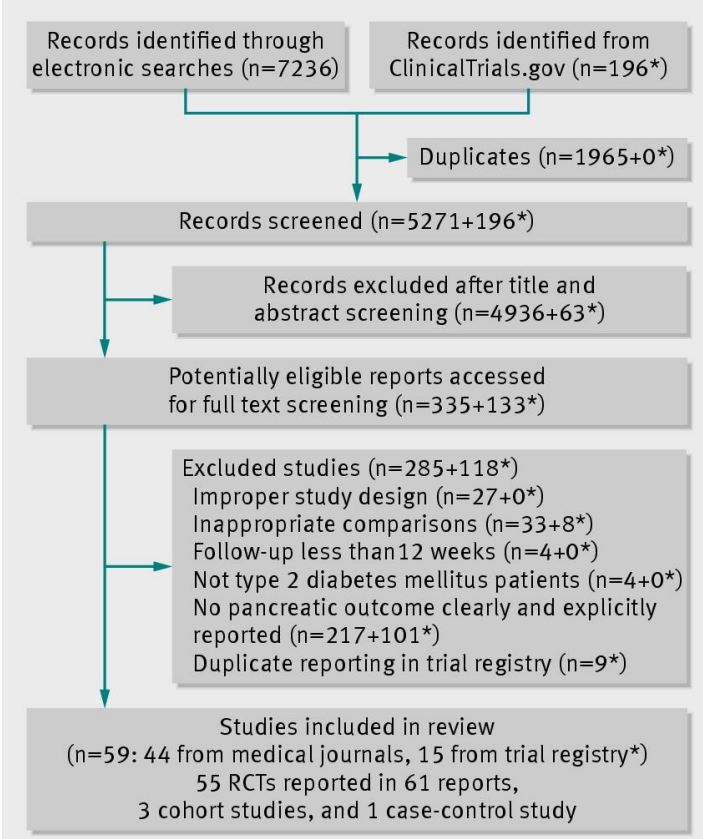

Fig 1 Flow chart of article selection. *Data from ClinicalTrials.gov 
Study

Araki 2013

Barnett 2012

Bergenstal 2010

Bunck 2009

Buse 2011

Chacra 2011

Diamant 2010

Fonseca 2012

Gallwitz 2012a

Gallwitz 2012b

Garber 2009

Grunberger 2012

Haak 2012

Henry 2012

Hollander 2011

Hollander 2012

Inagaki 2012

Kadowaki 2009

Kaku 2010

Kikuchi 2010

Kothny 2012

Marre 2009

Nauck 2009

Nauck 2013b

NCT000823812009

NCT00094770 2009

NCT001038572009

NCT00327015 2009

NCT00328172 2011

NCT00395512 2013

NCT00482729 2009

NCTO0 5755882010

NCT006149392011

NCT00722371 2011

NCT00757588 2011

NCT00954447 2012

NCT01137812 2013

NCT012042942012

NCT012891192013

Pan 2012

Pratley 2013

Ratner 2010

Raz 2012

Rosenstock 2009a

Rosenstock 2009b

Ross 2012

Russell-Jones 2009

Seino 2010

Seino 2012b

Umpierrez 2011

Yang 2011

Zinman 2009

Total $(95 \% \mathrm{Cl})$

Test for overall effect: $z=0.31, P=0.76$
Nauck 2013a

Russell-Jones 2012

Seino 2012a

No of events/total

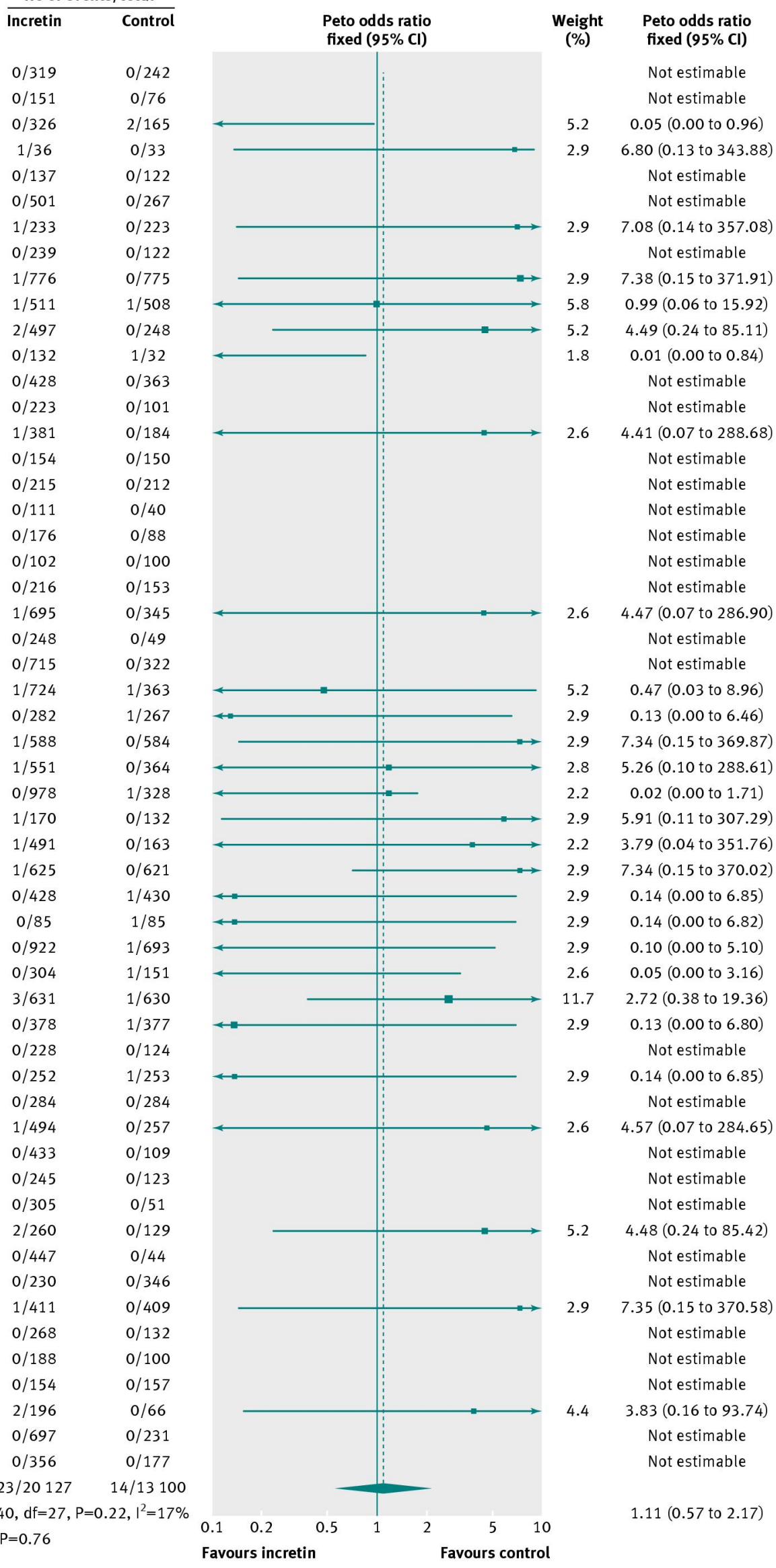

Fig 2 Risk of pancreatitis events between patients with type 2 diabetes mellitus treated with incretin or control 